\title{
The relationship between zinc, its isotopes, and the major nutrients in the North-East Pacific
}

\section{Journal Article}

\section{Author(s):}

Vance, Derek; De Souza, Gregory (1); Zhao, Ye; Cullen, Jay T.; Lohan, Maeve C.

Publication date:

2019-11-01

Permanent link:

https://doi.org/10.3929/ethz-b-000358046

Rights / license:

Creative Commons Attribution-NonCommercial-NoDerivatives 4.0 International

Originally published in:

Earth and Planetary Science Letters 525, https://doi.org/10.1016/j.epsl.2019.115748

\section{Funding acknowledgement:}

708407 - Southern Ocean Silicon Cycling: combining views of the past and present using silicon isotopes (EC) 
1 The relationship between zinc, its isotopes, and the major nutrients in the North2

$$
\text { Derek Vance }^{1 *} \text {, Gregory F. de Souza', Ye Zhao², Jay T. Cullen³, Maeve C. Lohan }{ }^{4}
$$

${ }^{1}$ Institute of Geochemistry and Petrology, Department of Earth Sciences, ETH Zürich, Clausiusstrasse 25, 8092 Zürich.

${ }^{2} \mathrm{Nu}$ Instruments Ltd, Unit 74 Clywedog Road South Industrial Estate, Wrexham LL13 9XS, UK.

${ }^{3}$ School of Earth and Ocean Sciences, University of Victoria, 3800 Finnerty Road, Victoria, British Columbia, Canada.

${ }^{4}$ School of Ocean and Earth Sciences, National Oceanography Centre, University of Southampton, Southampton, UK.

*Corresponding author: derek.vance@erdw.ethz.ch; phone +41 44632 6881; fax +41 446321376. 


\section{Abstract}

Trace metal micronutrients play key roles in photosynthesis by oceanic phytoplankton. Though they are required in much smaller amounts than the major nutrients $(\mathrm{P}, \mathrm{N}, \mathrm{Si})$, their bioavailable forms are also present in the seawater solution at much lower levels. Relationships between the dissolved chemistry of the nutrient-type trace metals, their stable isotope variations, as well those of the major nutrients, have highlighted the importance of biological and physical processes in the Southern Ocean in controlling their oceanic biogeochemistry. However, the first-order Southern Ocean processes are overprinted by vertical cycling in other parts of the ocean, particularly upwelling regions remote from the Southern Ocean, with the North Pacific standing out in particular. Here we present new zinc $(\mathrm{Zn})$ concentration and isotope, as well as major nutrient data for the NE Pacific, and couple these new data with a compilation of published data from across the region, with the objective of better understanding the impact of this important region on oceanic biogeochemical cycles.

The new $\mathrm{Zn}$ isotope data for two stations along Line P (P04 and P26) show a large range in $\delta^{66} \mathrm{Zn}$ in the upper ocean $(-0.4 \%$ up to $>1 \%$ ), associated with a very small isotope fractionation but extreme depletion of the dissolved pool during photic zone biological uptake, and the regeneration of this cellular $\mathrm{Zn}$ at very shallow depths $(50 \mathrm{~m})$. Beneath this, the two profiles approach the $\delta^{66} \mathrm{Zn}$ value of $+0.5 \%$, seen throughout the deep ocean, by about $500 \mathrm{~m}$. The minimum $\delta^{66} \mathrm{Zn}$ resulting from regeneration is associated with very high $\mathrm{Zn}$ concentrations, particularly at the marginal P04 station where diatoms dominate the phytoplankton ecology. Combining the new data with published Zn and major nutrient concentrations from across the North Pacific emphasises the role of vertical biological cycling in controlling regional biogeochemistry in the North Pacific, resulting in the partial overprinting of biogeochemical signatures transported out of the Southern Ocean by the ocean circulation. Zinc isotope data document the uptake of this metal into diatoms and the co-regeneration of $\mathrm{Zn}$ with phosphate in the upper water column. Silica in contrast is regenerated at greater depth, resulting in a decoupling of the $\mathrm{Zn}-\mathrm{Si}$ correlation that is set in the Southern Ocean and that dominates the Atlantic. Previous work has suggested that the decoupling of $\mathrm{Zn}$ and $\mathrm{Si}$ in the subarctic North Pacific results from removal of $\mathrm{Zn}$ (and other metals) to water column particulate sulphide. In our dataset, and in the compilation of data documenting relationships between $\mathrm{Zn}$ and the major nutrients across the North Pacific, this decoupling is clearly due to the different lengthscales of regeneration for organic matter (Zn and P) and diatom opal (Si). 


\section{Introduction}

Close to half the carbon fixation, and half the molecular oxygen production, on Earth is due to photosynthesis carried out by oceanic phytoplankton (Field et al. 1998). These organisms have absolute physiological requirements for certain trace metals, which act as essential components of the photosynthetic apparatus, as cofactors in enzymes essential for carbon fixation, and for the acquisition of major nutrients (e.g. Morel et al., 2014). While the cellular requirements of these metals are modest relative to the major algal nutrients $(\mathrm{P}, \mathrm{N}, \mathrm{Si})$, bioavailable concentrations of metals, and Fe in particular, can be small enough so as to limit the growth and influence the community composition of marine phytoplankton (Boyd et al., 2007; Bruland et al., 2014). Limitation or colimitation of cell growth and reproduction is less systemic for other metals, but has sometimes been demonstrated in culture (De La Rocha et al., 2000). It is also the case that cellular quotas relative to oceanic abundances are as high as, or higher than, Fe for certain metals in important organisms - e.g. $\mathrm{Zn}$ in diatoms (Twining and Baines, 2013).

The impact of these and other processes on the distributions of oceanic trace metals has been a topic of significant interest for decades (e.g. Bruland et al., 1980), but has received new impetus in recent years. Much more extensive, and higher spatial resolution, trace metal datasets have become available through the GEOTRACES programme (www.geotraces.org). This data revolution has in turn spurred renewed interest in both new and established observational approaches. For example, though relationships between the dissolved concentrations of trace metals and the major nutrients, and the dominant biological control on these relationships, have long been a focus (e.g. Bruland et al., 1980; Martin et al., 1989; Lohan et al., 2002; Janssen and Cullen, 2015), larger trace metal datasets have made this approach much more powerful. The stable isotope systems of these metals are much more recently developed tools, and researchers are beginning to exploit the timely coincidence of the advances in mass spectrometry and the availability of the clean, large, samples that permit this approach (e.g. Abouchami et al., 2011; Xue et al., 2013; Zhao et al., 2014; Cameron and Vance, 2014; Conway and John, 2014a,b; Conway and John, 2015; Xie et al., 2015).

One outcome of ocean-basin scale sections for trace metals has been the realisation that onedimensional vertical cycling of trace metal nutrients is only one of the key processes controlling their distributions in a three-dimensional ocean. Thus, for example, Vance et al. (2017) used relationships between dissolved $\mathrm{Zn}, \mathrm{Si}$ and $\mathrm{PO}_{4}$ to highlight the significance of uptake by Southern Ocean diatoms in creating biogeochemical signals which, when coupled to the physical ocean circulation, appear to 
control patterns in $\mathrm{Zn}-\mathrm{Si}-\mathrm{PO}_{4}$ co-variation on a near global scale. This extends to trace metals the concept of Southern Ocean control previously well-established as key to the global decoupling of silica and nitrate (Sarmiento et al., 2004, 2007). Similarly, the Southern Ocean and the water masses sourced there are emerging as key for global patterns in Cd distributions (e.g. Baars et al., 2014; Quay et al., 2015; Xie et al., 2015; Middag et al., 2018). In the case of Cd, specific isotope signals are also generated in the Southern Ocean and advected northwards in mode, intermediate and deep waters, at least as far as the Equator (e.g. Abouchami et al., 2011; Xue et al., 2013; Sieber et al., 2019).

The first-order significance of Southern Ocean biogeochemistry in explaining the origins of oceanic $\mathrm{Zn}-\mathrm{Si}-\mathrm{PO}_{4}$ co-variation, as well as the physics of the ocean circulation in transporting these signals globally (Vance et al., 2017; de Souza et al., 2018), has been confirmed by subsequent studies (Weber et al., 2018; Roshan et al., 2018; Middag et al., 2019). For example, Middag et al. (2019) suggest that no clear signal of in-situ vertical cycling processes is seen in data from the Atlantic. Two other recent large-scale studies have suggested that in the North Pacific the picture is somewhat less clear. Thus, while Weber et al. (2018) conclude that two thirds of the dissolved $\mathrm{Zn}$ in the deep North Pacific originates through uptake and regeneration in the Southern Ocean, they also highlight the potential importance of extra-Southern Ocean vertical cycling (both uptake and regeneration, and reversible scavenging) for the origin of the remaining third. Roshan et al. (2018) also suggest that $38 \pm 32 \%$ of the $\mathrm{Zn}$ in the deep North Pacific could originate through either extra-Southern Ocean uptake and regeneration, downward transfer by reversible scavenging, or addition of hydrothermal $\mathrm{Zn}$ to the deep ocean. With reference to the subarctic North Pacific in particular, a number of other recent studies (Janssen et al., 2014; Janssen and Cullen, 2015; Kim et al., 2017) have noted a decoupling of Cd and Zn distributions from those of the major nutrients. It has been suggested (Janssen et al., 2014; Janssen and Cullen, 2015) that there may be an impact on the distribution of these metals, particularly at intermediate levels, from water column sulphide precipitation in the low oxygen zones that characterise the NE Pacific.

It is perhaps unsurprising that it is particularly in the subarctic North Pacific that Southern Ocean signatures are overprinted by local basin or sub-basin-scale processes. Along with the North Atlantic, it is the ocean basin most remote from the Southern Ocean. Unlike the North Atlantic, there is no deep water formation in the North Pacific, and the major interior water mass of North Pacific origin, North Pacific Intermediate Water, is only seen in the subtropics (e.g. Yuan and Talley, 1996). The impact of local and basin-scale biological cycling is more likely to be strongly visible in the poorly ventilated waters in and below the subarctic gyres. Here we present new $\mathrm{Zn}$ isotope data that have a 
direct bearing on the issue of water column cycling of $\mathrm{Zn}$. We go further, however, to couple these new data with a compilation of published data from across the NE Pacific, and to compare patterns in the relationships between $\mathrm{Zn}$ and the major nutrients to global relationships. The picture that emerges suggests that local export of nutrients significantly overprints signals transported from outside the basin and that, together with the Southern Ocean, the subarctic North Pacific is an important location for export of $\mathrm{Zn}$ from the surface to the interior ocean.

\section{Oceanographic Setting}

The focus of this paper is the subarctic northeast Pacific. The locations from which the new data derive (white circles), and those for which we discuss published data (black squares), are shown in Fig. 1.

The northeast Pacific is subdivided by the Subarctic Front (Fig. 1) into the Alaska Gyre to the north and the northern part of the Subtropical Gyre to the south (e.g. Yuan and Talley, 1996). The Subarctic Front not only marks an abrupt change in physical properties, with colder and fresher water to the north, but also an important biogeochemical transition. To the south, surface waters are depleted in major nutrients, while the region to the north is classified as a high-nutrient low-chlorophyll (HNLC) region, with low standing phytoplankton stocks and significant residual major nutrient concentrations (e.g., Si, Fig. 1). Here, artificial enrichment experiments have shown Fe to be limiting to primary productivity (e.g. Martin et al., 1989; see Boyd et al., 2007 for a summary). Major nutrient concentrations decrease again north of $55^{\circ} \mathrm{N}$, and towards the Alaskan coast.

During late summer, in response to surface warming, the water column is characterised by a thin $(\sim 30$ m) mixed layer, which shoals towards the coast (e.g. Whitney and Freeland, 1999). Below this a permanent halocline occurs at around $100-150 \mathrm{~m}$, at the limit of winter storm and convective mixing. North Pacific Intermediate Water (NPIW; Yuan and Talley, 1996) does not significantly influence the study area and mesopelagic water is very poorly ventilated. Thus, the depth interval $500-2000 \mathrm{~m}$ is characterised by a low oxygen zone (Janssen and Cullen, 2015), with $\mathrm{O}_{2}$ concentrations $\leq 50 \mu \mathrm{mol}$ $\mathrm{kg}^{-1}$ at all stations shown in Fig. 1 (Martin et al., 1989; Janssen and Cullen, 2015; Conway and John, 2015). Radiocarbon is more depleted in these intermediate waters than any other part of the ocean (e.g. Östlund and Stuiver, 1980). These intermediate waters are sourced from abyssal waters below, and probably to the west, via upwelling and diapycnal transformation (Roemmich and McCallister, 
1989). The abyssal waters of Southern Ocean origin flow into the NE Pacific from the south and west (Roemmich and McCallister, 1989), and exhibit higher levels of oxygen and slightly younger radiocarbon ages (Östlund and Stuiver, 1980).

The microbial ecology and phytoplankton dynamics of the subarctic NE Pacific is of particular importance to the discussion of trace metals and their isotopes, as well as their relationships to the major nutrients, later in this paper. Upwelling in the middle of the cyclonic Alaskan gyre (Fig. 1) is marked by domed isotherms (Martin et al., 1989), bringing water rich in major nutrients to the surface. The first measurements of the concentrations of dissolved trace metals (Martin et al., 1989), as well as a number of $\mathrm{Fe}$ enrichment experiments (e.g. Martin et al., 1989; see Boyd et al., 2007 for summary), demonstrated the importance of Fe limitation in the open-ocean NE Pacific. Studies of phytoplankton ecology and export production have focused on Line P, and especially Ocean Station Papa (or P26, Fig. 1) in the HNLC region (e.g. Thibault et al., 1999; Boyd and Harrison, 1999). Here, chlorophyll- $a$ concentrations (chl- $a$ ) are usually around $0.2-0.4 \mu \mathrm{g} \mathrm{L}^{-1}$ throughout the mixed layer and year round, with primary production rates generally below $20 \mu \mathrm{g} \mathrm{C} \mathrm{L}^{-1}$ day $^{-1}$. There is little seasonal variation in standing stock, though primary production rates sometimes ascend as high as 30-40 $\mu \mathrm{g} \mathrm{C} \mathrm{L}^{-1}$ day $^{-1}$ in later summer (Thibault et al., 1999). In contrast, the marginal station P04 (Fig. 1) shows a very pronounced seasonal cycle in both standing stocks and primary production, similar to the open ocean station in winter, but sometimes exceeding $2 \mu \mathrm{g} \mathrm{L}^{-1}$ and $100 \mu \mathrm{g} \mathrm{C} \mathrm{L}^{-1}$ day $^{-}$ ${ }^{1}$ for chl- $a$ and primary production, respectively, in August-September. Station P04 exhibits a subsurface chlorophyll maximum (SCM, at around 15-30m) in late summer (Thibault et al., 1999; Boyd and Harrison, 1999).

The phytoplankton species composition also varies across Line P, both seasonally and spatially. The dominant cells, year round, found in the photic zone at P26 are prymnesiophytes and pelagophytes. In contrast, diatoms dominate in August-September at station P04 (Thibault et al., 1999). In the winter the phytoplankton population tends to be more diverse. Thibault et al. (1999) note that sediment traps recovered from 90-100m at station P26 contain more diatoms than photic zone cell populations would suggest, and conclude that sporadic aeolian Fe fertilisation events, leading to episodic diatom blooms, may not have been captured by their phytoplankton census. Boyd and Harrison (1999) present a similar picture, and conclude that diatoms are Fe-stressed in the open ocean NE Pacific but probably not at marginal locations, such as that of station P04. 


\section{Sampling and analytical methods}

The new data presented here derive from two stations at either end of Line P (white circles on Fig. 1). The samples were collected during a cruise in August 2011. Samples derive from the open ocean station P26 (Ocean Station Papa, at $\left.50^{\circ} \mathrm{N} 145^{\circ} \mathrm{W}\right)$, and the coastal station P04 (48.39 $\left.{ }^{\circ} \mathrm{N} 126.40^{\circ} \mathrm{W}\right)$. Rigorous contamination control procedures were used throughout sampling, with all critical handling steps onboard ship and onshore carried out in either a Class-100 laminar flow hood or a clean room. Samples were collected into acid-cleaned low-density polyethylene bottles. For depths $\leq 40 \mathrm{~m}$ water was pumped onboard via a trace metal clean Teflon pump and filtered directly through in-line $0.2 \mu \mathrm{m}$ polyethersulfone membrane filters (Pall AcroPak). Samples from depth $\geq 40 \mathrm{~m}$ were collected with acid-cleaned 12 litre Teflon-coated Go-Flo bottles attached to a powder-coated trace metal clean rosette. Upon recovery, seawater in the Go-Flo samplers was filtered under gravity through $0.2 \mu \mathrm{m}$ polyethersulfone membrane filters. Unfiltered samples were analysed for $\mathrm{Si}, \mathrm{NO}_{3}{ }^{-}$and $\mathrm{PO}_{4}{ }^{3-}$ according to Barwell-Clarke and Whitney (1996). Dissolved $\mathrm{O}_{2}$ data was obtained with a Seabird SBE43 dissolved oxygen sensor calibrated against Winkler titrations. Nutrient and $\mathrm{O}_{2}$ data are courtesy of the Line P Program (Chief Scientist Marie Robert, Institute of Ocean Sciences, Canada). Water samples for chlorophyll analysis were filtered onto Whatman GF/F filters, and extracted with 90\% acetone for fluorometric analysis (Strickland and Parsons, 1972).

The methods for isotopic analysis of the NE Pacific samples were identical to those we have described in extensive detail previously (Zhao et al., 2014). Briefly, samples were double-spiked prior to preconcentration of $\mathrm{Zn}$ by co-precipitation with added aluminium hydroxide, column purification and analysis by MC-ICPMS. The blank for this process was $2-3 \times 10^{-9} \mathrm{~g}(\mathrm{ng}) \mathrm{Zn}$, compared to a processed sample size of 50-500 ng, with the exception of 3 near-surface samples at station P04 (10-30 ng). All samples have had a correction applied for this blank (with a $\delta^{66} \mathrm{Zn}$ value of $0.17 \pm 0.18 \%$ ), and this results in the high analytical uncertainties for the near-surface station P04 samples. The uncertainties reported for most other samples correspond to the analytical reproducibility of $\pm 0.07 \%$ (2SD). Zn concentrations, $[\mathrm{Zn}]$, were obtained by isotope dilution. Uncertainties in [Zn], based on duplicate analysis performed in this laboratory, are $<5 \%$.

\section{Results}

The new $\mathrm{Zn}$ concentration and isotope data are presented in Table 1, and shown as depth profiles in 
Figs 2 and 3, together with data for the major nutrients and chl- $a$ obtained on the same cruise. Zinc concentration data are available for stations P04 and P26 from three previous studies (Martin et al., 1989; Lohan et al., 2002; Janssen and Cullen, 2015), and these data are also compared with those obtained here in Figs 2 and 3.

A key feature of station P04 (Fig. 2) that is apparent from all these studies is a particularly rapid increase in dissolved $\mathrm{Zn}$ concentrations from the very low values at the surface. In the dataset for both winter and summer 1999, this increase continues to at least $400 \mathrm{~m}$, where concentrations reach $14 \mathrm{nM}$. In 2011 the rapid increase in the upper 50m matches that for the 1999 data, but there is a maximum at 50-70m, after which concentrations decline again to levels close to the shallowest samples measured in August 2012. The prominent Zn concentration maximum is mirrored by a maximum in both $\mathrm{Zn} / \mathrm{Si}\left(>0.6 \mathrm{mmol} \mathrm{mol}^{-1}\right.$ ) and $\mathrm{Zn} / \mathrm{P}$ (up to $6 \mathrm{mmol} \mathrm{mol}^{-1}$ ). It is important to note that these features of the upper $100 \mathrm{~m}$ are defined by several data in the 2011 profile, as well as by data from 1999. The maxima in [ $\mathrm{Zn}], \mathrm{Zn} / \mathrm{Si}$, and $\mathrm{Zn} / \mathrm{P}$ correspond to a pronounced minimum in $\delta^{66} \mathrm{Zn}$, of $-0.2 \%$. Above this minimum, three data points are heavier, and these occur at depths where chl- $a$ is high, though shallower than the chl- $a$ maximum. Beneath its minimum, $\delta^{66} \mathrm{Zn}$ increases slowly with depth to the value of around $+0.5 \%$ that characterises much of the deep ocean (e.g. Zhao et al., 2014; Conway and John, 2014b; John et al., 2018; Wang et al., 2019). The station P04 isotope profile generally matches that for the subtropical North Pacific station SAFe extremely well (Conway and John, 2015).

Though data for station P26 are also generally consistent with previous studies (Fig. 3), conditions at this location did differ in August 2011 in several important respects. For example, chl- $a$ concentrations show a distinct maximum in the photic zone in August 2011, at levels greater than station P04, a feature that is not usual for this location (Thibault et al., 1999; Boyd and Harrison, 1999). Similarly, [Zn] and Zn/P are somewhat higher right at the surface than found previously. Zinc concentrations, $\mathrm{Zn} / \mathrm{Si}$ and $\mathrm{Zn} / \mathrm{P}$ all show minima at the base of the mixed layer and a steep gradient down to about $150 \mathrm{~m}$. Zinc concentration and $\mathrm{Zn} / \mathrm{P}$ continue to increase more slowly beneath this depth, while $\mathrm{Zn} / \mathrm{Si}$ ratios show a maximum at $150 \mathrm{~m}$, decreasing slowly below. Zinc isotopes show a minimum similar to station P04, but at P26 this minimum is more pronounced (-0.4\%o) and shallower $(25 \mathrm{~m})$. As at station P04, $\delta^{66} \mathrm{Zn}$ above this minimum is heavy, though there is only one datum, and beneath it there is the same slow increase to the deep ocean value of $+0.5 \%$. The minimum in $\delta^{66} \mathrm{Zn}$ occurs within the interval of high chl- $a$ in the upper $50 \mathrm{~m}$. Beneath about $600 \mathrm{~m}$, the isotope data again 
match those for SAFe (Fig. 3), but the P26 profile increases to the value of $+0.5 \%$ o that characterises the deep ocean at a much shallower depth $-150-200 \mathrm{~m}$ versus $600-800 \mathrm{~m}$.

\section{Discussion}

\subsection{Data comparisons along Line $P$}

Fig. 4 compares data for the two stations studied here, at either end of Line P, with published data for stations in between (Lohan et al., 2002; Janssen and Cullen, 2015). On Fig. 4 the marginal station P04 clearly stands out, being characterized by very prominent excursions in [Zn], Zn/Si and $\mathrm{Zn} / \mathrm{P}$ in the 50-100m depth range. As noted earlier, our findings here are consistent with the fact that diatoms dominate the phytoplankton at station P04 in summer (Thibault et al., 1999). For example, diatom cells are well-established to have very high $\mathrm{Zn} / \mathrm{P}$ ratios (e.g. Twining and Baines, 2013) so that the particularly low dissolved ratios in the upper 20m at station P04 are consistent with uptake. The excursion to values as high as $6 \mathrm{mmol} \mathrm{mol}^{-1}$ at $50-100 \mathrm{~m}$, just below the mixed layer, is best explained by co-regeneration of $\mathrm{Zn}$ and $\mathrm{P}$ from this pool at close to the cellular ratio (Twining et al., 2014). The excursion to high $\mathrm{Zn} / \mathrm{Si}$ at the same level is consistent with the above scenario, given the deeper levels for opal dissolution versus organic matter respiration.

High $\mathrm{Zn} / \mathrm{Si}$ ratios in the upper subarctic NE Pacific generally were first pointed out by Lohan et al. (2002), who also noted a pattern of decreasing upper-ocean $\mathrm{Zn} / \mathrm{Si}$ ratio with distance offshore. The depth profiles in Fig. 4 reinforce this pattern, but also emphasise that the enrichment in $\mathrm{Zn}$ is particularly prominent in the immediate sub-surface. This is striking at station P04 as noted above, but it also relatively obvious at station P12 (Fig. 4). On the other hand, by stations P20 and P26 further to the west it has largely disappeared. This spatial pattern is also consistent with previous work on the microbial ecology along Line P. Thibault et al. (1999) report that diatoms, though not dominant as at station P04, still constitute a significant proportion of the algal population at station P12. On the other hand, other algal groups (prymnnesiophytes, pelagophytes) dominate further offshore. We suggest that it is cycling of $\mathrm{Zn}$ via uptake into the organic matter of diatom cells, together with regeneration of this $\mathrm{Zn}$ in the immediate sub-surface, that maintains this very shallow sub-surface pattern in the more eastward stations along Line P.

At offshore stations (P16, P20, P26), Zn concentrations increase relatively slowly and monotonically with depth in the upper $100 \mathrm{~m}$ of the water column. At all offshore stations concentrations then increase much more rapidly beneath $100 \mathrm{~m}$, reaching values close to their deep ocean maximum 
between 200 and $600 \mathrm{~m}$. Again there is a spatial pattern, with the deep ocean value reached at $200 \mathrm{~m}$ at station P26 versus 600m at stations P04 and P12. This rapid change between the photic zone and the deep ocean, also noted earlier for $\mathrm{Zn}$ isotopes at P26, occurs at depths that closely correspond to the permanent halocline. At P26, beneath $100 \mathrm{~m}, \mathrm{Zn}$ is virtually conservative with salinity. The eastwest pattern, we will show later, is actually radial, and is controlled by upwelling centred on the Alaska Gyre.

\subsection{Upper ocean controls on $\mathrm{Zn}$ isotopes in the North Pacific and beyond}

There is currently debate over what controls $\mathrm{Zn}$ isotopes in the upper ocean. Intense biological drawdown in the surface Southern Ocean appears not to be associated with a significant isotope effect (e.g. Zhao et al., 2014; Wang et al, 2019; Sieber et al., in review). Thus, surface water here, despite extreme depletion of $\mathrm{Zn}$, is not isotopically different from deep water. As a result, all water masses exported from the Southern Ocean, despite $\mathrm{Zn}$ concentrations that differ by two orders of magnitude, are identical in $\delta^{66} \mathrm{Zn}$ at close to $+0.5 \%$. Outside the Southern Ocean, large datasets for $\mathrm{Zn}$ isotopes from the North Atlantic and South Pacific (Conway and John, 2014b; John et al., 2018) demonstrate that upper ocean $\mathrm{Zn}$ is up to $1.5 \%$ lighter than the deep ocean, not heavier as would be expected from in-situ biological drawdown. We suggest that these observations pose two different questions: (1) is biological cycling within the upper ocean regime inconsistent with culture studies that suggest uptake of the light isotope and; (2) why is the low latitude upper ocean as a whole isotopically light? The data in this paper are directly relevant to question (1) above. We return briefly to question (2) at the end of this section.

Culturing studies (John et al., 2007; John and Conway, 2014; Köbberich and Vance, 2017, 2018; Samanta et al., 2018) have demonstrated that a range of organisms take up the light isotopes of $\mathrm{Zn}$ relative to the bulk culture media. John et al. (2007) demonstrated that, at the concentrations relevant to the real ocean, the apparent fractionation is small, corresponding to a difference between the bulk

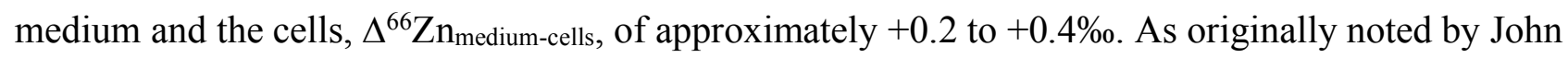
et al. (2007), and reinforced by Köbberich and Vance (2019), this difference is actually consistent with no difference between the isotope composition of free $\mathrm{Zn}$ in the culture medium and that taken up, given that most medium $\mathrm{Zn}$ is complexed to EDTA and that EDTA-complexed $\mathrm{Zn}$ is 0.3 to $0.4 \%$ o heavier than the free $\mathrm{Zn}$ species (Markovic et al., 2017). However, $\mathrm{Zn}$ in almost the entire global surface ocean (except for the Southern Ocean) is organically-complexed like the $\mathrm{Zn}$ in culturing 
media so that, since cells take up free Zn (Sunda and Huntsman, 1992), the cells should still be enriched in the light isotopes relative to the dissolved pool. Markovic et al. (2017) present experimental findings showing that isotope fractionation between free $\mathrm{Zn}$ and the organically-bound complex depends on the thermodynamic stability constant for that complex, which for EDTA is about 6 orders of magnitude greater than those for the molecules that chelate $\mathrm{Zn}$ in the ocean (e.g., Bruland, 1989; Ellwood and van den Berg, 2000; Markovic et al., 2017). On the other hand, Bruland (1989) also showed that the conditional stability constants for Zn-EDTA complexes in seawater are lower than those for natural organic ligands, due to side reactions between EDTA and $\mathrm{Ca}$ and $\mathrm{Mg}$ ions that do not occur for the natural ligands (Bruland et al., 1989). Whatever the precise reason, it is clear that surface $\mathrm{Zn}$ isotopes barely shift in residual surface seawater north of the upwelling zone in the Southern Ocean, despite the uptake of about $95 \%$ of the upwelled $\mathrm{Zn}$ pool into diatom cells (Zhao et al., 2014; Wang et al., 2019).

In the upper $50 \mathrm{~m}$ or so of the sub-Antarctic zone of the Pacific, $\mathrm{Zn}$ is heavier than the sub-surface (Samanta et al., 2017). Moreover, variations in $\mathrm{Zn}$ isotopes in the upper $150 \mathrm{~m}$ correlate positively with chl- $a$, consistent with uptake of light $\mathrm{Zn}$ and its regeneration beneath the chlorophyll maximum. Haptophytes are the main phytoplankton group in this region. In a companion study (Samanta et al., 2018), these same authors demonstrated that cultured Emiliana huxleyi cells are enriched in the light isotope relative to bulk media, by about $0.4 \%$. The authors note the similarity between this apparent isotope fractionation determined in culture and the isotopic differences observed by Samanta et al. (2017) across a range of depths in the real ocean. However, the isotopic spread in the water column across a concentration gradient does not equate to the fractionation factor for uptake seen in culture, since the shallow subsurface concentration and isotopic gradients are the result of a complex interplay between biological cycling and ocean mixing/transport. As a consequence, it is difficult to quantify the fractionation factor from in-situ seawater data. For a closed-system Rayleigh model, the data of Samanta et al. (2017) imply only a very small fractionation $-\leq 0.1 \%$ - between bulk seawater $\mathrm{Zn}$ and that taken up. On the other hand, such a Rayleigh model neglects the impact of mixing, and may underestimate the fractionation factor when applied across a strong concentration gradient. In the Supplementary Information, we use a simple 1D model to roughly assess the impact of mixing. Using realistic values for upwelling velocity and turbulent diffusivity, this model suggests that the fractionation could be as high as $0.2-0.3 \%$.

To a large extent the pattern found by Samanta et al. (2017) is also seen here for the NE Pacific data, though the relationship between the location of $\delta^{66} \mathrm{Zn}$ minima and maxima to those of chl- $a$ are not 
as straightforward (Figs. 2, 3). In the case of both stations studied here, the surface-most $\delta^{66} \mathrm{Zn}$ datum is heavy while the sub-surface is light. Though the surface return to heavy $\mathrm{Zn}$ isotopes is defined by a single datum for station P26, for station P04 it is better resolved. As discussed in section 5.1, all the evidence for station $\mathrm{P} 04$ points to the cycling of $\mathrm{Zn}$ in the upper $200 \mathrm{~m}$ via uptake into and regeneration from diatom cells. Given the uncertainties and scatter in the data, the difference in $\delta^{66} \mathrm{Zn}$ between the mixed layer and the immediate sub-surface is about 0.5-1\%o. Again, however, this does not represent the degree to which the diatom cells take up light Zn. As for the Samanta et al. (2017) data, a simple 1D model that includes realistic physical parameters suggests that the data for $\mathrm{Zn}$ abundance and isotopes in the upper $200 \mathrm{~m}$ at station P04 could imply preferential uptake of the light isotope, as for Samanta et al. (2017), by 0.2-0.3\%o (Supplementary Information).

The finding of slightly light $\mathrm{Zn}$ isotopes in the immediate sub-surface relative to the surface is actually ubiquitous, was first made by Bermin et al. (2006), and keeps recurring (e.g. Zhao et al., 2014; Wang et al., 2019). In terms of the North Atlantic, where the most extreme case of an overall light upper ocean can be found, Wang et al. (2019) show that more than half the depth profiles presented in Conway and John (2014b) actually show a pattern whereby the surface-most data are heavier than the immediate sub-surface. Thus, the pattern of $\mathrm{Zn}$ isotope variation within the upper ocean is not necessarily inconsistent with culture studies

Regarding question (2) from earlier, explanations of the main processes driving the isotope composition of the tiny low latitude upper ocean pool have, naturally, focused on removal processes such as in-situ biologically-driven export or scavenging (e.g. Bermin et al., 2006; Zhao et al., 2014; Conway and John, 2014b; John et al., 2018). Since the isotope composition of the upper ocean is light overall, this has led to the suggestion that the removal process favours the heavy isotope (e.g. John and Conway, 2014; Conway and John, 2014b; Weber et al., 2018). However, this interpretation overlooks an important ambiguity. The ultimate origin of upper-ocean water found in the low latitudes, and the $\mathrm{Zn}$ it contains, lies in subduction in the sub-Antarctic region (de Souza et al., 2018). Zinc has largely been stripped from this water by diatom uptake and export. The very low upper ocean $\mathrm{Zn}$ concentrations are thus largely the result of distal biological drawdown in the Southern Ocean - i.e., the low $\mathrm{Zn}$ concentration of the low latitude upper ocean is to a large extent a preformed signal transported northwards from the Southern Ocean. Given this preformed low-Zn signal, it is not at all clear whether any subsequent process involves removal or addition. Certainly, the scavenging sink proposed by other workers is vanishingly small (adsorbed $\mathrm{Zn}<0.01-0.5 \%$ of total $\mathrm{Zn}$; Weber et 
al., 2018), and given the sensitivity of the very small upper ocean pool of $\mathrm{Zn}$ to any perturbation, addition of isotopically light $\mathrm{Zn}$ is also a viable option, one that needs to be more fully addressed in future work.

\subsection{Is there significant removal of $\mathrm{Zn}$ to sulphide in the sub-surface NE Pacific?}

In an analysis of variations in $\mathrm{Zn}$ concentrations and $\mathrm{Zn} / \mathrm{Si}$ ratios, with depth and along Line $\mathrm{P}$, Janssen and Cullen (2015) showed that Zn and Si concentrations are slightly decoupled in the NE Pacific in comparison with other parts of the world ocean. Specifically, these authors hypothesised the preferential removal of $\mathrm{Zn}$ from the water column as solid $\mathrm{Zn}$ sulphides form in particularly anoxic microenvironments around remineralising organic material, at depth levels where $\mathrm{O}_{2}$ falls below about $60 \mu \mathrm{M}$, in low oxygen zones. That there is a degree of $\mathrm{Zn}-\mathrm{Si}$ decoupling in the NE Pacific is beyond doubt. The key data are plotted in Fig. 5, which shows the current as well as other data from Line P as well as data from other North Pacific sites in Fig. 1 (Martin et al., 1989; Lohan et al., 2002; Janssen and Cullen, 2015; Conway and John, 2015).

The observation that led Janssen and Cullen (2015) to suggest decoupling is the fact that data in the NE Pacific lie off and above the Zn-Si correlation as defined globally (e.g. the black line on Fig. 5A from Vance et al., 2017), so that the correlation has a distinct convex-upwards nature. The suggestion in Janssen and Cullen (2015) is that Zn and Si data from the NE Pacific effectively lie on two different straight-line segments - one for the well-oxygenated upper ocean where $\mathrm{Zn}$ and Si increase together because of regeneration, and one for the low oxygen zone where Si concentrations continue to increase with depth but $\mathrm{Zn}$ concentrations level off due to removal into putative sulphidic particulates.

One issue with this interpretation is that, in fact, the $\mathrm{Zn}-\mathrm{Si}$ correlation is never completely linear. Vance et al. (2017) emphasised the fact that the major Southern Ocean-sourced upper ocean water mass, Sub-Antarctic Mode Water (SAMW), has its origin in subduction from the mixed layer. This physical feature greatly diminishes the importance of the fact that the regeneration length scales of organic material versus opal are different (e.g. Berelson, 2001; Ragueneau et al., 2002). In simple terms, if diatom uptake and growth can remove $\mathrm{Zn}$ and Si together from the surface mixed layer, relative to $\mathrm{PO}_{4}$, the resulting low $\mathrm{Zn} / \mathrm{P}$, low $\mathrm{Si} / \mathrm{P}$ signal will be imprinted on water masses subducted from that layer, whilst $\mathrm{Zn}$ - and Si-rich biogenic particles are exported into the deep Southern Ocean, where their decomposition and dissolution will lead to an enrichment in both $\mathrm{Zn}$ and Si. This coupled 
export outweighs the differences between the lengthscales of regeneration of organic matter (with the $\mathrm{Zn}$ ) and opal (with the $\mathrm{Si}$ ), and produces a correlation between these two elements. However, even in the Southern Ocean the Zn-Si relationship is slightly convex upwards (Fig. 5A), and in fact the convex-upward nature of the NE Pacific relationship is simply a more pronounced version of the same thing.

This suggestion receives strong support through comparison of depth profiles of the major nutrients in the NE Pacific with that for excess Zn (Fig. 6). In Fig. 6, excess Zn relative to the global Zn-Si

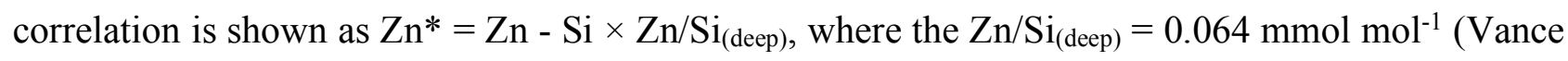
et al., 2017). Fig. 6A shows that there is indeed a reversal in $\mathrm{Zn} *$ at about $300 \mathrm{~m}$, at the same depth level at which $\mathrm{O}_{2}$ concentrations decrease to $<100 \mu \mathrm{mol} \mathrm{kg}{ }^{-1}$. However, beneath that depth level $\mathrm{Zn}$ remains in excess: $\mathrm{Zn}^{*}$ is far above zero. The $\mathrm{Zn} *$ peak at around $300 \mathrm{~m}$ is a result of intense regeneration of $\mathrm{Zn}$ with $\mathrm{PO}_{4}$ (Fig. 6B) above that level, equivalent to the steep lower portion of the $\mathrm{Zn}-\mathrm{Si}$ correlation, while opal dissolution is much more modest. The reversal in $\mathrm{Zn} *$ at around $300 \mathrm{~m}$, equivalent to the break in slope in the $\mathrm{Zn}$-Si correlation (Fig. 5A), is similarly driven by the deeper regeneration of silica from opal (Fig. 6C) accompanied by very little further increase in $\mathrm{Zn}\left(\right.$ and $\left.\mathrm{PO}_{4}\right)$ through regeneration.

Thus, we suggest that the convex-upwards nature of the $\mathrm{Zn}-\mathrm{Si}$ relationship is, mainly, a simple consequence of three important controls: (1) $\mathrm{Zn}$ in phytoplankton, including diatoms, is nearly exclusively located in organic material (e.g. Twining and Baines, 2013); (2) as a result, $\mathrm{Zn}$ and $\mathrm{PO}_{4}$ are regenerated together, at the $\mathrm{Zn} / \mathrm{PO}_{4}$ ratio of the cell, in the upper ocean (Twining et al., 2014); (3) the lengthscale of regeneration of opal is greater. These controls, while always a factor to some degree as shown by the Southern Ocean data in Fig. 5A, become more important in regions of the ocean, like the subarctic NE Pacific, where the combination of high particulate fluxes and limited ventilation of the shallow subsurface allows biogeochemical signals of local nutrient cycling to build up in the water column. Thus, the data that stand out on Fig. 5A are those for station P04, forming their own trend with very high $\mathrm{Zn} / \mathrm{Si}$ ratio, which we attribute to the dominance of diatoms at this location, their very high $\mathrm{Zn}$ contents and the fact that this $\mathrm{Zn}$ is regenerated from organic material at very shallow levels. The high $\mathrm{Zn} / \mathrm{PO}_{4}$ ratio of diatoms also make these data stand out on the $\mathrm{Zn}-\mathrm{PO}_{4}$ correlation

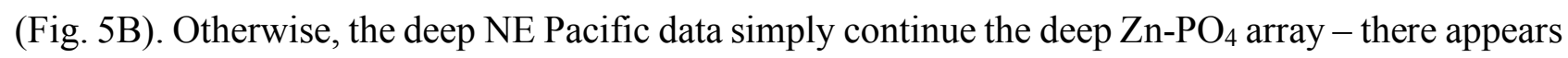
to be very little room for removal of $\mathrm{Zn}$ relative to $\mathrm{PO}_{4}$ in the oxygen-deficient zone of the NE Pacific. Clearly, on the two plots in Fig. 5, it is silica concentrations in the deep Pacific that stand out: in other 
words, the cause of the convex-upwards nature of the $\mathrm{Zn}$-Si correlation is not preferential removal of $\mathrm{Zn}$ in the sub-surface, rather it is preferential regeneration of $\mathrm{Zn}$ in the upper ocean and preferential dissolution of opal in the deep.

\subsection{Regional-scale features of the distributions of major nutrients and metal micronutrients in the NE Pacific}

The previous section highlighted the fact that decoupling of $\mathrm{Zn}$ and Si in the NE Pacific arises through differential remineralisation of $\mathrm{Zn}$ and $\mathrm{Si}$ with depth, with $\mathrm{Zn}$ sourced with phosphorus from sinking organic material in the upper ocean while $\mathrm{Si}$ is sourced from opal deeper in the water column. We contend that this is simply a manifestation of processes that occur elsewhere, but are more readily visible here because of relatively sluggish circulation, long sub-surface residence times (e.g. Östlund and Stuiver, 1980) and high particulate fluxes in a region of general upwelling (e.g. Honjo et al., 2008). We examine this further, as well as other aspects of the subarctic NE Pacific in particular, via a north-south sequence of stations from SAFe $\left(35^{\circ} \mathrm{N}\right.$, Fig. 1; Conway and John, 2015) to T9 $\left(58.5^{\circ} \mathrm{N}\right.$; Martin et al., 1989), using depth profiles (Fig. 7), plots against potential density (Fig. 8) and sections at specific depths (Fig. 9).

Many features of the depth profiles, going from north to south, coincide with those noted by Janssen and Cullen (2015) proceeding west along Line P. Thus, both westward along Line P (Fig. 4) and northwards from SAFe as far as station $\mathrm{T} 8\left(55.5^{\circ} \mathrm{N}\right)$ on Fig. 7 , the $\mathrm{Zn}$ concentration data shift away from continuously increasing profiles with depth (station P04 versus P26, station SAFe versus T8) toward profiles with two distinct sections: first, rapidly increasing Zn concentrations down to $400 \mathrm{~m}$ or so, followed by rather flat profiles versus depth. The $\mathrm{Zn} / \mathrm{P}$ depth profiles mirror those of $\mathrm{Zn}$ concentrations almost perfectly, again emphasising the similarity in the depths of the remineralisation of these two elements. And, again, the contrast with $\mathrm{Si}$ is emphasised by the depth profile for $\mathrm{Zn} / \mathrm{Si}$, with a shoaling and sharpening of the $\mathrm{Zn} / \mathrm{Si}$ peak (Fig. 7) proceeding northwards. It is important that the final station in the north-south sequence considered here - station T9 at $59.5^{\circ} \mathrm{N}$, north of the centre of the Alaska gyre - shows a reversal in all these trends, so that its depth profiles are similar to those for station $\mathrm{T} 6$, at $45^{\circ} \mathrm{N}$. Thus, the biogeochemical pattern of variation in the NE Pacific is, in fact, radially centred on the Alaska gyre, and is almost certainly related to upwelling. Indeed, the variation with depth at stations in the centre of the gyre look like classical advection-dominated profiles. Moreover, the variations in the shapes of depth profiles across line P (Fig. 4) are also seen in the north-south sequence (Fig. 7), but these differences largely disappear in the potential density plots 
(Fig. 8). The differences that remain between stations in Fig. 8 are also intriguing. For example, the two stations in the centre of the gyre (P26 and T8) show an enrichment in Zn relative to all other stations at low densities $\left(\sim 25.7-26.5 \mathrm{~kg} / \mathrm{m}^{3}\right)$ that correspond to the very shallowest subsurface water column $(\sim 50-150 \mathrm{~m})$ at these stations. This feature - also visible in $\mathrm{Zn} / \mathrm{P}$ and $\mathrm{Zn} / \mathrm{Si}$ in Fig. 8 - is, again, extremely suggestive of a net source of $\mathrm{Zn}$ to sub-mixed layer waters, caused by enhanced regeneration of $\mathrm{Zn}$ within the upwelling Alaskan gyre. In this context, it is worth noting that Kim et al. (2017) invoke remineralisation of Zn-rich biogenic particles as a potential cause of the shallow Zn-enrichment observed in the western and central subarctic North Pacific.

These diagrams also show again that, in the context of variations in nutrient concentrations with depth, it is silica that stands out as different in its behaviour versus depth in the NE Pacific. Thus, for stations in the Alaska Gyre at $50-60^{\circ} \mathrm{N}$, both phosphate and the metals reach values within $10 \%$ of their maxima, at about 300-400m (Fig. 9). This is emphasised for $\mathrm{Zn}$ by the $\mathrm{Zn} / \mathrm{P}$ ratio depth profile in Fig. 7. Clearly, Zn and Cd are remineralised with phosphate in the upper $400 \mathrm{~m}$. Silica, alone, shows a significant increase between 300 and $1000 \mathrm{~m}$, and a smaller increase between 1000 and 1500m (Fig. 9). The remineralisation of opal in the deep ocean is reflected in the fact that Si concentrations, in contrast to phosphate and the metals, almost double between $300-400 \mathrm{~m}$ and $1500-2000 \mathrm{~m}$, whilst the $\mathrm{Zn} / \mathrm{Si}$ ratio halves from its peak at 200-400m, at all stations.

\section{Conclusions}

In this paper we have presented new $\mathrm{Zn}$ concentration and isotope data for two stations in the NE Pacific (Line P), and have compared the new data with $\mathrm{Zn}$ abundance patterns, and their relationship to the major nutrients, across the NE Pacific. The new $\mathrm{Zn}$ isotope data are consistent with a small (0.2-0.3 \%o) isotope fractionation during uptake in the photic zone, with preferential uptake of the light isotope, that is consistent with both Southern Ocean data (Zhao et al., 2014; Wang et al., 2019; Sieber et al., in review) and culture experiments (John et al., 2007; Samanta et al., 2018; Köbberich and Vance, 2019). The isotopically-light cellular $\mathrm{Zn}$ is regenerated at very shallow levels, resulting in high dissolved $\mathrm{Zn}$ concentrations and an isotope minimum at about 50-100m, analogous to the subsurface $\mathrm{Cd}$ isotope minima produced by shallow regeneration in Southern Ocean upwelling regimes (Xue et al., 2013; Sieber et al., 2019). Beneath this regeneration maximum $\delta^{66} \mathrm{Zn}$ approaches the deep ocean average as seen elsewhere. These patterns are particularly clear at the marginal station (P04) where previous work (Thibault et al., 1999) have documented the dominance of diatoms in the phytoplankton ecology. 
528 Combining the new data with published $\mathrm{Zn}$ and major nutrient concentrations from across the North 529 Pacific, confirms the role of vertical biological cycling in controlling regional biogeochemistry in the 530 North Pacific. Even in the North Pacific (c.f. Weber et al., 2018), however, and to an even greater 531 extent in the Atlantic (Middag et al., 2019), these vertical processes are superimposed on the dominant 532 global pattern that originates through advection northwards of Southern Ocean water masses (Vance 533 et al., 2017; de Souza et al., 2018). In the North Pacific, the vertical cycling processes as well as the 534 clear co-regeneration of $\mathrm{Zn}$ and phosphate from organic matter in the upper ocean and the deeper regeneration of $\mathrm{Si}$, partially decouples $\mathrm{Zn}$ and $\mathrm{Si}$ covariation. Our interpretation greatly deemphasises the role of low oxygen zones in driving this decoupling. Though we not that we cannot discount this latter process completely, our analysis suggests little need to invoke additional upperocean $\mathrm{Zn}$ removal other than by cellular uptake, either by removal into sulphides or any other abiotic process.

\section{Acknowledgements}

We thank the Captain and crew of the CCGS J.P. Tully and Chief Scientist and head of the Line P Time Series program Marie Robert for supporting this research. We are grateful to Dr. Christina Schallenberg for help with trace metal clean sampling and the Department of Fisheries and Ocean's Canada for pigment and nutrient analyses on the August 2011 cruise. This research was supported by ETH Zürich and the Swiss National Science Foundation (SNF) through grant 200020-16590 (to DV), and by EU Horizon 2020 through a Marie Skłodowska-Curie Research Fellowship (SOSiC; 708407) to GFdS. MCL's trace metal research is supported by NERC grant NE/N001125/1. JTC was supported by a Natural Sciences and Engineering Research Council (NSERC) Discovery Grant. We thank two anonymous reviewers for their comments, and editor Laura Robinson for very efficient editorial handling. 


\section{References}

Abouchami, W.F. et al., 2011. Modulation of the Southern Ocean cadmium isotope signature by ocean circulation and primary productivity. Earth Planet. Sci. Lett. 305, 83-91.

Baars, O., Abouchami, W., Galer, S.J.G., Boye, M., Croot, P.L., 2014. Dissolved cadmium in the Southern Ocean: Distribution, speciation and relation to phosphate, Limnol. Oceanogr. 59, 385-399.

Barwell-Clarke, J., Whitney, F., 1996. Institute of Ocean Sciences nutrient methods and analysis. Can. Tech. Rep. Hydrogr. Ocean Sci. 182, 1-43.

Berelson,W. M., 2001. The flux of particulate organic carbon into the ocean interior: a comparison of four US JGOFS regional studies. Oceanography 14, 59-67.

Bermin, J., Vance, D., Archer, C., Statham, P.J., 2006. The determination of the isotopic composition of $\mathrm{Cu}$ and $\mathrm{Zn}$ in seawater. Chem. Geol. 226, 280-297.

Boyd, P.W., Harrison, P.J., 1999. Phytoplankton dynamics in the NE subarctic Pacific. Deep-Sea Res. II 46, 2405-2432.

Boyd, P.W. et al., 2007. Mesoscale iron enrichment experiments 1993-2005: synthesis and future directions. Nature 315, 612-617.

Boyer, T.P., et al., 2013: World Ocean Database 2013, NOAA Atlas NESDIS 72, S. Levitus, Ed., A. Mishonov, Technical Ed.; Silver Spring, MD, 209 pp., http://doi.org/10.7289/V5NZ85MT.

Bruland, K.W., 1980. Oceanographic distributions of cadmium, zinc, nickel and copper in the North Pacific. Earth Planet. Sci. Lett. 47, 176-198.

Bruland, K.W. et al., 2014. Controls of trace metals in seawater. Treatise on Geochemistry 8, 19-51.

Cameron, V., Vance, D., 2014. Heavy nickel isotope compositions in rivers and the oceans. Geochim. Cosmochim. Acta 128, 195-211.

Conway, T.M., John, S.G., 2014a. Quantification of dissolved iron sources in the North Atlantic Ocean. Nature 511, 212-215.

Conway, T.M., John, S.G., 2014b. The biogeochemical cycling of zinc and zinc isotopes in the North Atlantic Ocean. Global Biogoechem. Cycles 28, 1111-1128.

Conway, T.M., John, S.G., 2015. The cycling of iron, zinc and cadmium in the North East Pacific Ocean - insights from stable isotopes. Geochim. Cosmochim. Acta 164, 262-283.

De La Rocha, C.L., Hutchins, D.A., Brzezinski, M.A., Zhang, Y., 2000. Effects of iron and zinc deficiency on elemental composition and silica production by diatoms. Mar. Ecol. Progr. Ser. 195, 71-79.

de Souza, G.F., Khaitwala, S.P., Hain, M.P., Little, S.H., Vance, D., 2018. On the origin of the marine zinc-silicon correlation. Earth Planet. Sci. Lett. 492, 22-34.

Field, C.B., Behrenfeld, M.J., Randerson, J.T., Falkowski, P., 1998. Primary production of the biosphere: integrating terrestrial and oceanic components. Science 281, 237-240.

Honjo, S., Manganini, S.J., Krishfeld, R.A., Fancois, R., 2008. Particulate organic carbon fluxes to the ocean interior and factors controlling the biological pump : a synthesis of global sediment trap programs since 1983. Prog. Oceanogr. 76, 217-285.

Janssen, D.J. et al., 2014. Undocumented water column sink for cadmium in open ocean oxygendeficient zones. Proc. Natl. Acad. Sci. 111, 6888-6893. 
Janssen, D.J., Cullen, J.T., 2015. Decoupling of zinc and silicic acid in the subarctic northeast Pacific interior. Mar. Chem. 177, 124-133.

John, S.G., Geis, R.W., Saito, M.A., Boyle, E.A., 2007. Zn isotope fractionation during high-affinity and low-affinity zinc transport by the marine diatom Thalassiosira oceanica. Limnol. Oceanogr. 52, 2710-2714.

John, S.G., Conway, T.M., 2014. A role for scavenging in the marine biogeochemical cycling of zinc and its isotopes. Earth Planet. Sci. Lett. 394, 159-167.

John, S.G., Heloge, J. Townsend, E., 2018. Biogeochemical cycling of Zn and Cd and their stable isotopes in the Eastern Tropical South Pacific. Mar. Chem. 201, 256-262.

Kim, T., Obata, H., Nishioka, J., Gamo, T., 2017. Distribution of dissolved Zn in the western and central subarctic North Pacific. Glob. Biogeochem. Cycles 31, 1454-1468.

Köbberich, M., Vance, D., 2017. Kinetic control on Zn isotope signatures recorded in marine diatoms. Geochim. Cosmochim. Acta 210, 97-113.

Köbberich, M., Vance, D., 2019. The ligand control on zinc isotope fractionation during uptake into marine phytoplankton: implications for oceanic zinc isotopes. Chem. Geol, in press.

Lohan, M.C., Statham, P.J., Crawford, D.W., 2002. Total dissolved zinc in the upper water column of the subarctic North East Pacific. Deep-Sea Res. II 49, 5793-5808.

Markovic, T. et al., 2017. Experimental determination of zinc isotope fractionation in complexes with the phyterosiderophore 2'-Deoxymugeneic Acid (DMA) and its structural analogues and implications for plant uptake mechanisms. Environ. Sci. Technol. 51, 98-107.

Marshall, J., Speer, K., 2012. Closure of the meridional overturning circulation through Southern Ocean upwelling. Nature Geoscience 5, 171-180.

Martin, J.H., Gordon, R.M., Fitzwater, S., Broenkow, W.W., 1989. VERTEX: phytoplankton/iron studies in the Gulf of Alaska. Deep-Sea Res. 36, 649-680.

Middag, R., van Heuven, M.A.C., Bruland, K.W., de Baar, H.J.W., 2018. The relationship between cadmium and phosphate in the Atlantic Ocean unravelled. Earth Planet. Sci. Lett. 492, 79-88.

Middag, R., de Baar, H.J.W., Bruland, K.W., 2019. The relationship between dissolved zinc and major nutrients phosphate and silicate along the GEOTRACES GA02 transect in the west Atlantic Ocean. Glob. Biogeochem. Cycles 33, 63-84.

Morel, F.M.M., Milligan, A.J., Saito, M.A., 2014. Marine bioinorganic chemistry: the role of trace metals in the oceanic cycles of the major nutrients. Treatise on Geochemistry 8, 123-150.

Östlund, H.G., Stuiver, M., 1980. GEOSECS Pacific radiocarbon. Radiocarbon 22, 25-53.

Quay, P., Cullen, J., Landing, W. and Morton, P., 2015. Processes controlling the distributions of Cd and $\mathrm{PO}_{4}$ in the ocean. Global Biogoechem. Cycles 29, 830-841.

Ragueneau, O., Dittert, N., Pondaven, P., Treguer, P. \& Corrin, L., 2002. Si/C decoupling in the world ocean: is the Southern Ocean different? Deep-Sea Res. 49, 3127-3154.

Roemmich, D., McCalliser, T., 1989. Large scale circulation of the North Pacific Ocean. Prog. Oceanog. 22, 171-204.

Roshan, S., DeVries, T., Wu, J., Chen, G., 2018. The internal cycling of zinc in the ocean. Glob. Biogeochem. Cycles 32, 1833-1849. 
Samanta, M., Ellwood, M.J., Sinoir, M., Hassler, C.S., 2017. Dissolved zinc isotope cycling in the Tasman Sea, SW Pacific Ocean. Mar. Chem. 192, 1-12.

Samanta, M., Ellwood, M.J., Strzepek, R.F., 2018. Zinc isotope fractionation by Emiliania huxleyii cultured across a range of free zinc ion concentrations. Limnol. Ocenaogr. 63, 660-671.

Sarmiento, J.L., Gruber, N., Brzezinski, M.A., Dunne, J.P., 2004. High-latitude controls of thermocline nutrients and low latitude biological productivity. Nature 427, 56-60.

Sarmiento, J.L. et al., 2007. Deep ocean biogeochemistry of silicic acid and nitrate. Global Biogeochem. Cycles 21, 10.1029/2006GB002720.

Sieber, M., Conway, T.M., de Souza, G.F., Takano, S., Sohrin, Y., Vance, D., 2019. Physical and biogeochemical controls on the distribution of dissolved cadmium and its isotopes in the southwest Pacific Ocean. Chem. Geol. 511, 494-509.

Sieber, M., Conway, T.M., de Souza, Ellwood, M.H., Vance, D., in review. Cycling of zinc and its isotopes across multiple zones of the Southern Ocean: insights from the Atlantic Circumnavigation Expedition. Geochim. Cosmochim. Acta, in review.

Sinoir, M. et al., 2016. Zinc cycling in the Tasman Sea: distribution, speciation and relation to phytoplankton community. Mar. Chem. 182, 25-37.

Strickland, J. D. H., Parsons, T.R., 1972. A Practical Handbook of Seawater Analysis. Fisheries Research Board of Canada Bulletin 167, Ottawa, 2nd edition.

Sunda, W.G., Huntsman, S.A., 1992. Feedback interactions between zinc and phytoplankton in seawater. Limnol. Oceanogr. 37, 25-40.

Thibault, D., Roy, S., Wong, C.S., Bishop, J.K., 1999. The downward flux of biogenic material in the NE subarctic Pacific: importance of algal sinking and mesozooplankton herbivory. Deep-Sea Res. II, 2669-2697.

Twining, B.S., Baines, S.B., 2013. The trace metal composition of marine phytoplankton. Ann. Rev. Mar. Sci. 5, 191-215.

Twining, B.S. et al. (2014) Differential remineralization of major and trace elements in sinking diatoms. Limnol. Oceanogr. 59, 689-704.

Vance, D., Little, S.H., de Souza, G.F., Khaitwala, S.P., Lohan, M.C. Middag, R., 2017. Silicon and zinc biogeochemical cycles coupled through the Southern Ocean. Nature Geoscience 10, 202-206.

Wang, R.M., Archer, C., Bowie, A.R., Vance, D., 2019. Zinc and nickel isotopes in seawater from the Indian Sector of the Southern Ocean: the impact of natural iron fertilization versus Southern Ocean hydrography and biogeochemistry. Chem. Geol. 511, 452-464.

Weber, T., John, S., Tagliabue, A., DeVries, T., 2018. Biological uptake and reversible scavenging of zinc in the global ocean. Science 361, 72-76.

Whitney, F.A., Freeland, H.J, 1999. Variability in upper-ocean water properties in the NE Pacific Ocean. Deep-Sea Res. II 46, 2351-2370.

Xie, R. et al., 2015. The cadmium-phosphate relationship in the western South Atlantic - the importance of mode and intermediate waters on the global systematics. Mar. Chem. 177, 110-123.

Xue, Z. et al., 2013. Cadmium isotope variations in the Southern Ocean. Earth Planet. Sci. Lett. 382, 161-172.

Yuan, X., Talley, L.D., 1996. The subarctic frontal zone in the North Pacific: characteristics of frontal structure from climatological data and synoptic survey. J. Geophys. Res. 101, 16,491-16,508. 
675 Zhao, Y., Vance, D., Abouchami, W., de Baar, H.J.W., 2014. Biogeochemical cycling of zinc and its 676 isotopes in the Southern Ocean. Geochim. Cosmochim. Acta 125, 653-672. 
Table 1: Zn concentration, isotopic and major nutrient data for the NE Pacific.

\begin{tabular}{|c|c|c|c|c|c|c|c|}
\hline $\begin{array}{l}\text { Depth } \\
\text { m }\end{array}$ & $\begin{array}{c}{[\mathbf{Z n}]} \\
\mathrm{nmol} \mathrm{kg}^{-1}\end{array}$ & $\begin{array}{c}\delta^{66} \mathrm{Zn}^{1} \\
\% 0 \\
\end{array}$ & $2 \sigma$ & Salinity & $\begin{array}{c}{\left[\mathrm{PO}_{4}\right]} \\
\mu \mathrm{M}\end{array}$ & $\begin{array}{l}{[\mathbf{S i}]} \\
\mu \mathbf{M}\end{array}$ & $\begin{array}{c}{\left[\mathrm{NO}_{3}\right]} \\
\mu \mathrm{M} \\
\end{array}$ \\
\hline \multicolumn{8}{|c|}{ P04, NE Pacific, $48.39^{\circ} \mathrm{N}, 126.40^{\circ} \mathrm{W}$} \\
\hline 10 & 0.09 & 0.43 & 0.11 & 32.183 & 0.28 & 2.5 & 0 \\
\hline 25 & 0.08 & 1.17 & 0.30 & 32.253 & 0.31 & 3.2 & 0 \\
\hline 40 & 0.96 & 0.31 & 0.07 & 32.412 & & & \\
\hline 50 & 3.95 & -0.22 & 0.07 & 32.518 & 0.68 & 6.4 & 3.7 \\
\hline 75 & 4.07 & -0.06 & 0.07 & 32.507 & 0.97 & 8.6 & 9.4 \\
\hline 100 & 3.20 & 0.08 & 0.07 & 32.647 & 1.45 & 20 & 17.4 \\
\hline 150 & 3.49 & 0.22 & 0.07 & 32.657 & 2.01 & 34.9 & 28.0 \\
\hline 200 & 5.05 & 0.28 & 0.07 & 33.079 & 2.16 & 43.5 & 30.9 \\
\hline 250 & 6.17 & 0.21 & 0.07 & 33.033 & & & \\
\hline 300 & 7.36 & 0.34 & 0.07 & 33.757 & 2.57 & 60.6 & 36.6 \\
\hline 600 & 10.1 & 0.49 & 0.07 & 33.768 & 3.16 & 96.1 & 43.7 \\
\hline 800 & 10.4 & 0.45 & 0.07 & 33.888 & & & \\
\hline 1000 & 9.11 & 0.52 & 0.07 & 33.891 & 3.28 & 127 & 45.1 \\
\hline 1200 & 10.3 & 0.52 & 0.07 & 33.925 & 3.24 & 136 & 44.3 \\
\hline
\end{tabular}

\section{P26, NE Pacific, $50^{\circ} \mathrm{N}, 145^{\circ} \mathrm{W}$}

$\begin{array}{lccccccc}10 & 0.65 & 0.25 & 0.13 & 32.519 & 1.10 & 16.0 & 11.6 \\ 25 & 0.88 & -0.38 & 0.13 & 32.517 & 1.11 & 15.9 & 11.7 \\ 40 & 1.01 & 0.17 & 0.07 & 32.512 & 1.34 & 11.0 & 13.6 \\ 50 & 1.09 & 0.29 & 0.07 & 32.519 & 1.49 & 27.0 & 17.2 \\ 100 & 1.95 & 0.42 & 0.07 & 32.648 & 1.69 & 32.5 & 21.1 \\ 150 & 6.03 & 0.40 & 0.07 & 32.750 & 2.42 & 61.0 & 34.4 \\ 200 & 7.24 & 0.50 & 0.07 & 32.733 & 2.67 & 73.0 & 38.6 \\ 300 & 7.88 & 0.58 & 0.07 & 32.811 & 2.89 & 87.8 & 42.5 \\ 600 & 8.68 & 0.57 & 0.07 & 32.797 & 3.11 & 119 & 45.0 \\ 1000 & 9.75 & 0.49 & 0.07 & 33.680 & 3.18 & 147 & 45.8 \\ 1400 & 9.97 & 0.56 & 0.07 & 33.675 & 3.18 & 160 & 45.0 \\ 2000 & 9.83 & 0.49 & 0.07 & 33.773 & 3.01 & 171 & 43.8\end{array}$




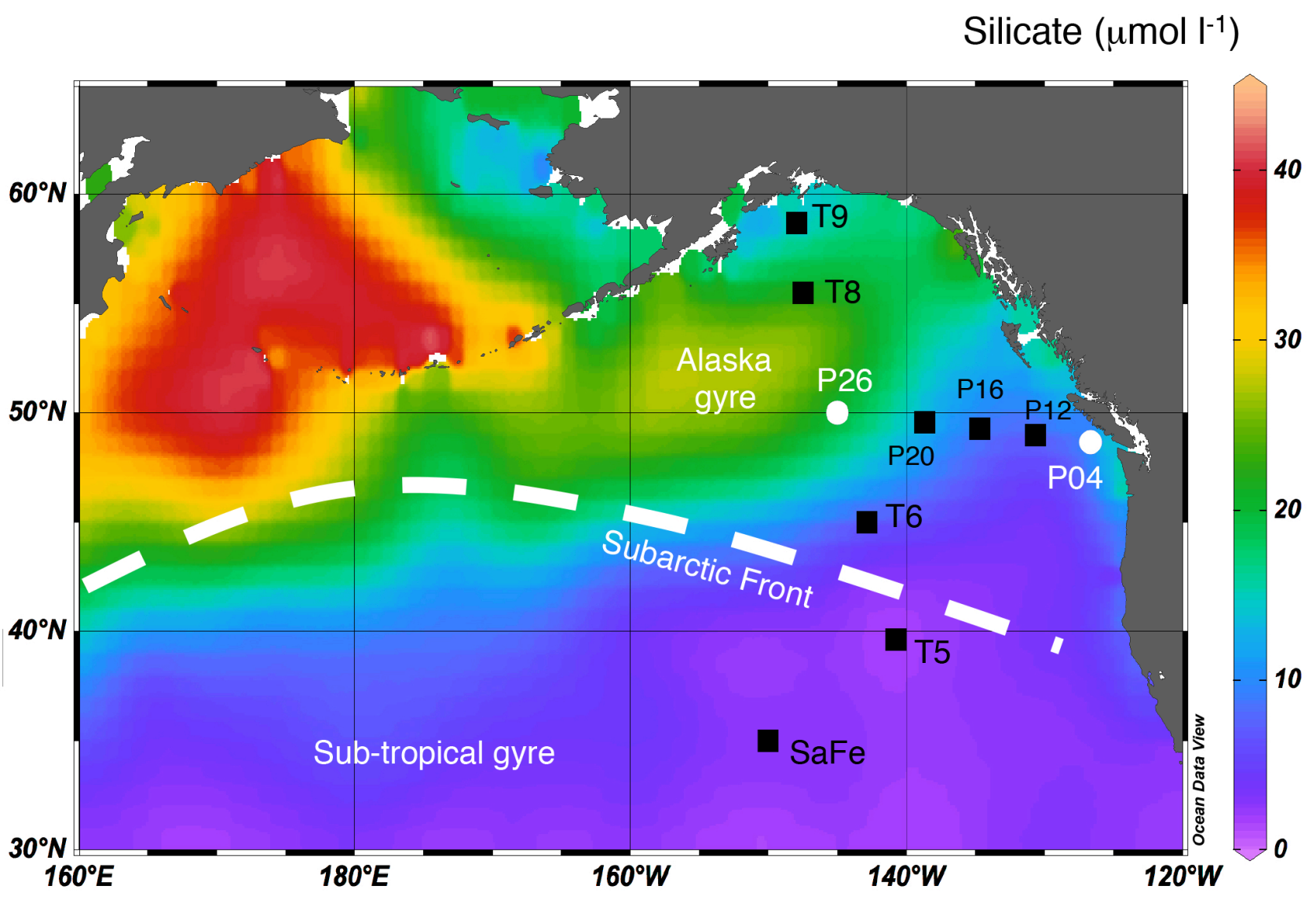

Figure 1: Map of the northeast Pacific, showing surface annually-averaged dissolved silicate concentrations (World Ocean Atlas; Boyer et al., 2013), with the locations of the two stations for which new Zn concentration and isotope data are presented here (white circles, stations P04 and P26). Other stations for which published data are discussed here are shown as black squares (SaFe: Conway and John, 2015; VERTEX stations T5-T9; Martin et al., 1989). Previously published data for Zn and major nutrient concentrations are also available for stations P04, P26 and other line P stations (Lohan et al., 2002; Janssen and Cullen, 2015) and are also discussed here. The approximate position of the 696 northern boundary of the Subarctic Front (white dashed line) is taken from Yuan and Talley (1996). 


\section{Vance et al. - Figure 2}

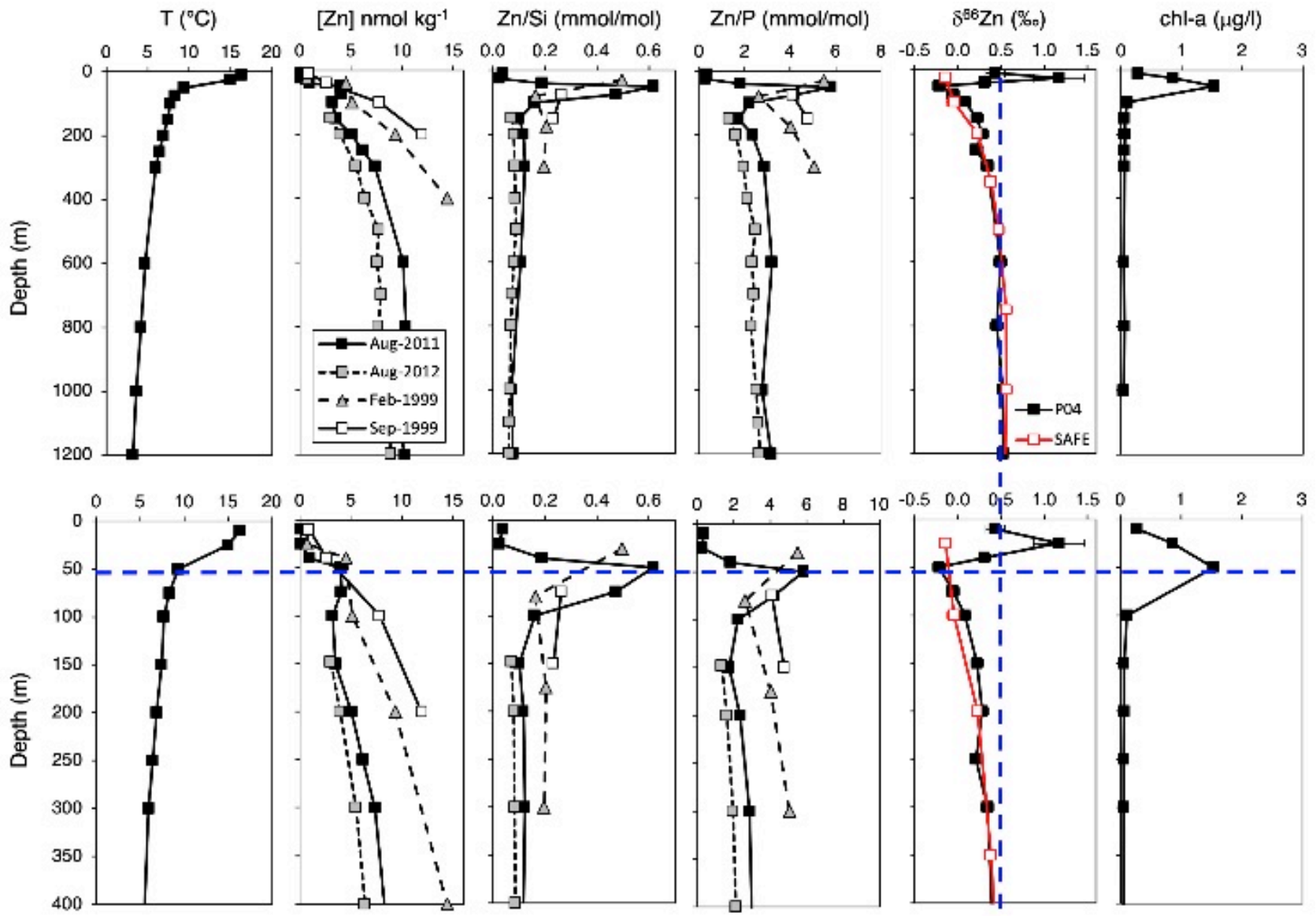

Figure 2: Depth profiles of temperature, $\mathrm{Zn}$ concentration, $\mathrm{Zn} / \mathrm{Si}, \mathrm{Zn} / \mathrm{P}, \delta^{66} \mathrm{Zn}$ and fluorescence-based chl- $a$ for station P04 for August 2011 (black filled squares in all panels). The full profiles are shown at the top and a more detailed view of the upper $400 \mathrm{~m}$ at the bottom. The vertical blue line in the isotope plots marks a value of $+0.5 \%$, typical of the deep Pacific and close to the average deep ocean value for other regions of the ocean (Zhao et al., 2014; Conway and John, 2014b; Conway and John, 2015; Samanta et al., 2017; John et al., 2018). The horizontal blue line marks the level of the chlorophyll maximum as derived from calibrated fluorescence measurements. The $\mathrm{Zn}, \mathrm{Zn} / \mathrm{Si}$ and $\mathrm{Zn} / \mathrm{P}$ profiles show data from this study (August 2011) as well as data from previously published studies (Aug 2012: Janssen and Cullen, 2015; Feb. and Aug. 1999: Lohan et al., 2002). The isotope profiles also show data for the SAFe station (Conway and John, 2015). 


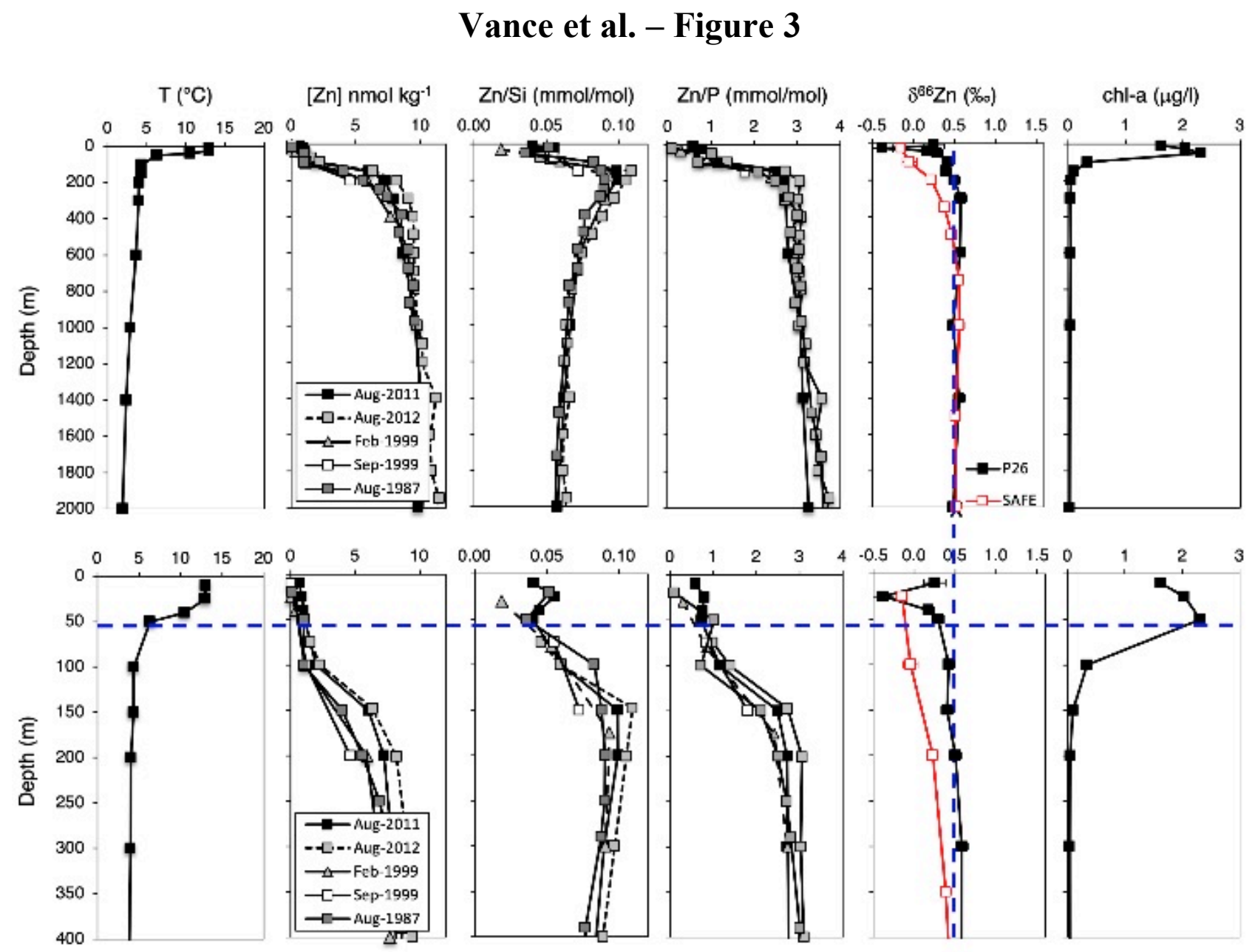

Figure 3: Depth profiles of temperature, $\mathrm{Zn}$ concentration, $\mathrm{Zn} / \mathrm{Si}, \mathrm{Zn} / \mathrm{P}, \delta^{66} \mathrm{Zn}$ and chl- $a$ for station P26 for August 2011 (black filled squares in all panels). The full profiles are shown at the top and a more detailed view of the upper $400 \mathrm{~m}$ at the bottom. The vertical blue line in the isotope plots marks a value of $+0.5 \%$, typical of the deep Pacific and close to the average deep ocean value for other regions of the ocean (Zhao et al., 2014; Conway and John, 2014b; Conway and John, 2015; Samanta et al., 2017; John et al., 2018). The horizontal blue line marks the level of the chlorophyll maximum as derived from calibrated fluorescence measurements. The $\mathrm{Zn}, \mathrm{Zn} / \mathrm{Si}$ and $\mathrm{Zn} / \mathrm{P}$ profiles show data from this study (August 2011) as well as data from previously published studies (Aug 2012: Janssen and Cullen, 2015; Feb. and Aug. 1999: Lohan et al., 2002; Aug. 1987: Martin et al., 1989). The isotope profiles show data for the SAFe station (Conway and John, 2015). 


\section{Vance et al. - Figure 4}
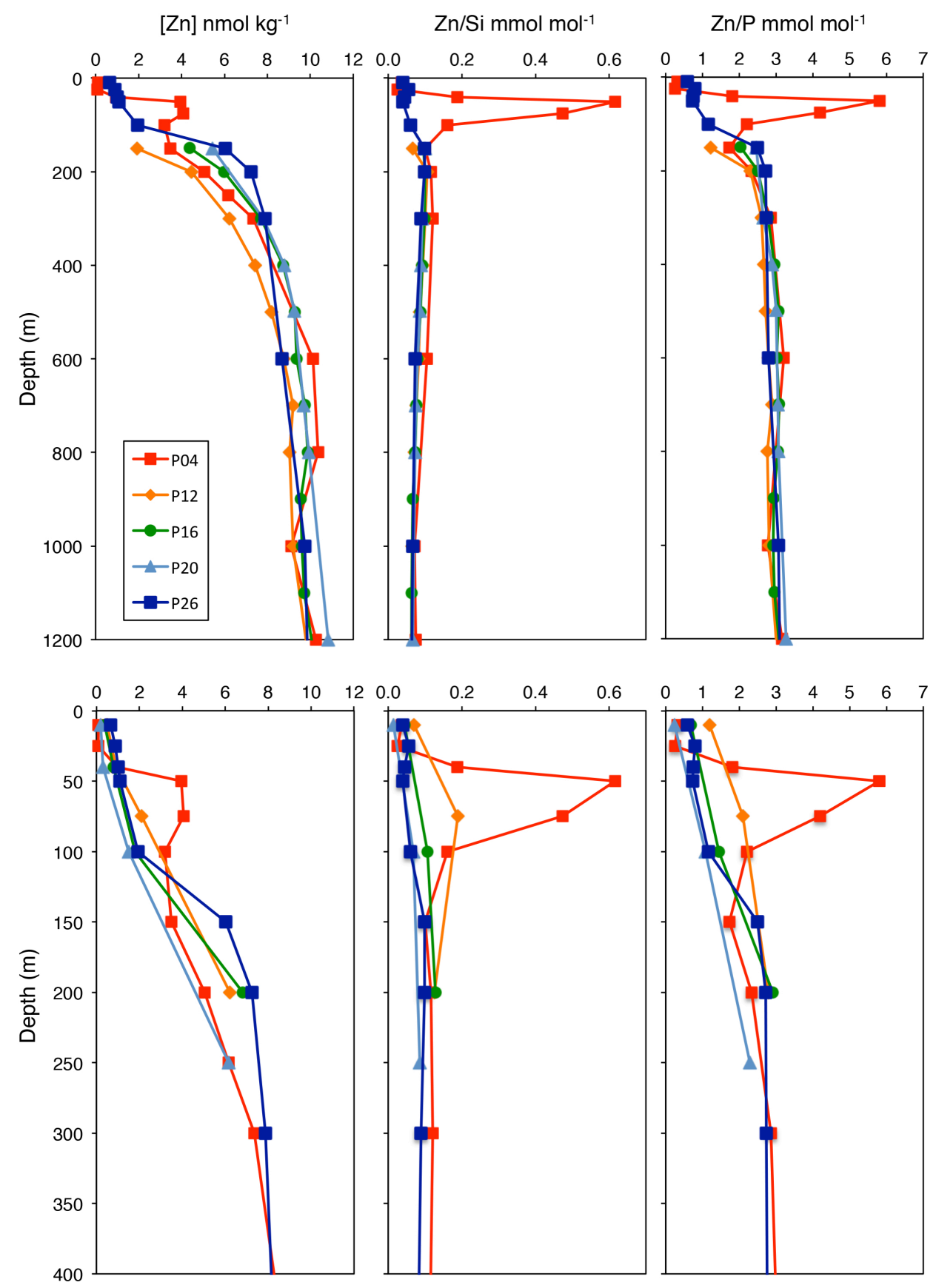

Figure 4: Depth profiles of $\mathrm{Zn}$ concentration, $\mathrm{Zn} / \mathrm{Si}$ and $\mathrm{Zn} / \mathrm{P}$, comparing data from this study for stations P04 and P26 for August 2011 with published data for other Line P stations. The locations of all stations plotted are shown on Fig. 1. The full profiles are shown at the top and a more detailed view of the upper $400 \mathrm{~m}$ at the bottom. For the top panels the data obtained here are compared with those for August 2012 in Janssen and Cullen (2015). No data are reported in the latter paper for the upper $150 \mathrm{~m}$ so that the expanded profiles at the bottom use the data of Lohan et al. (2002) for September 1999. 


\section{Vance et al. - Figure 5}
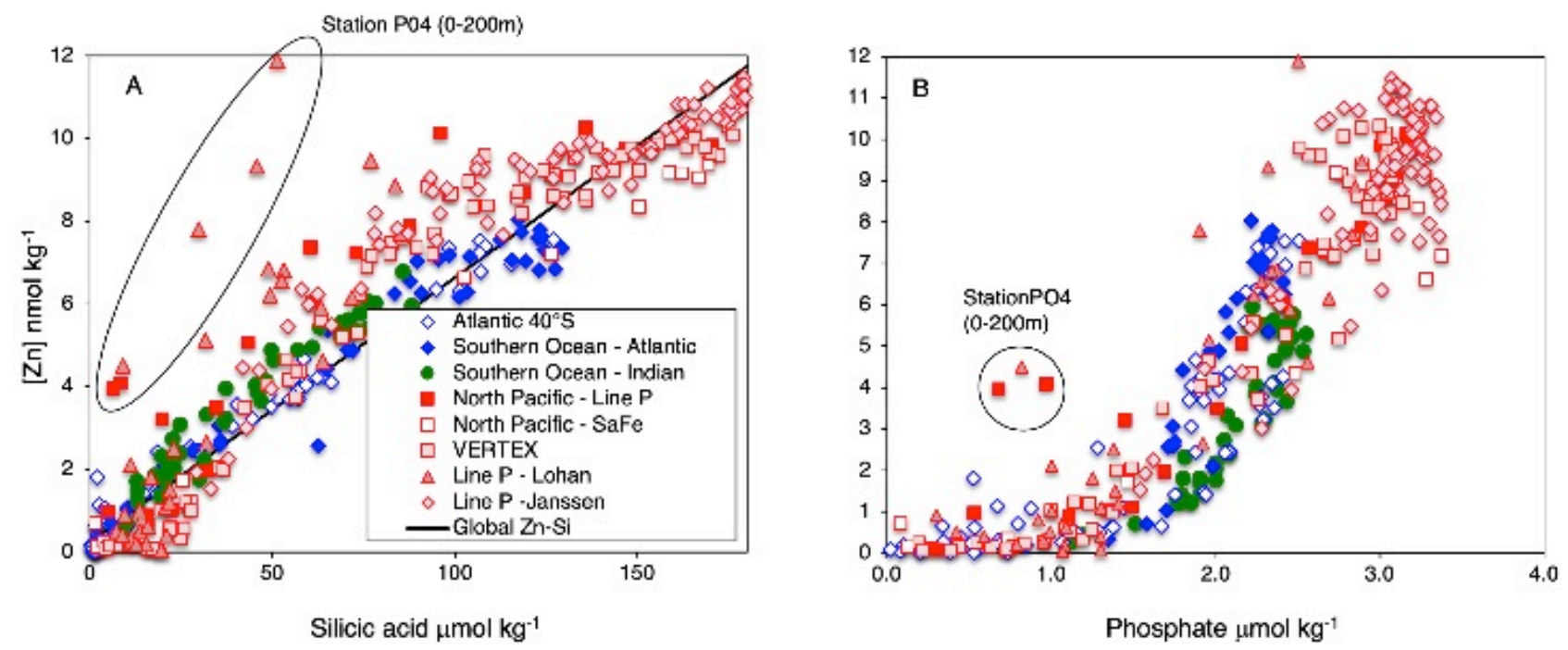

Figure 5: $\mathrm{Zn}$ versus silica (A) and $\mathrm{Zn}$ versus phosphate (B) for water column samples from the NE Pacific (this study: North Pacific - Line P; other Line P data from Lohan et al. (2002) and Janssen and Cullen (2015); SAFe (Conway and John, 2015); VERTEX (Martin et al, 1989)) compared to data for the Southern Ocean (Atlantic data from Zhao et al., 2014; Indian data from Wang et al., 2019) and the South Atlantic (Wyatt et al., 2014). Data for specific samples at Station P04, from this study and from Lohan et al. (2002) are highlighted. The line labelled Global Zn-Si is from Vance et al. (2017). 


\section{Vance et al. - Figure 6}

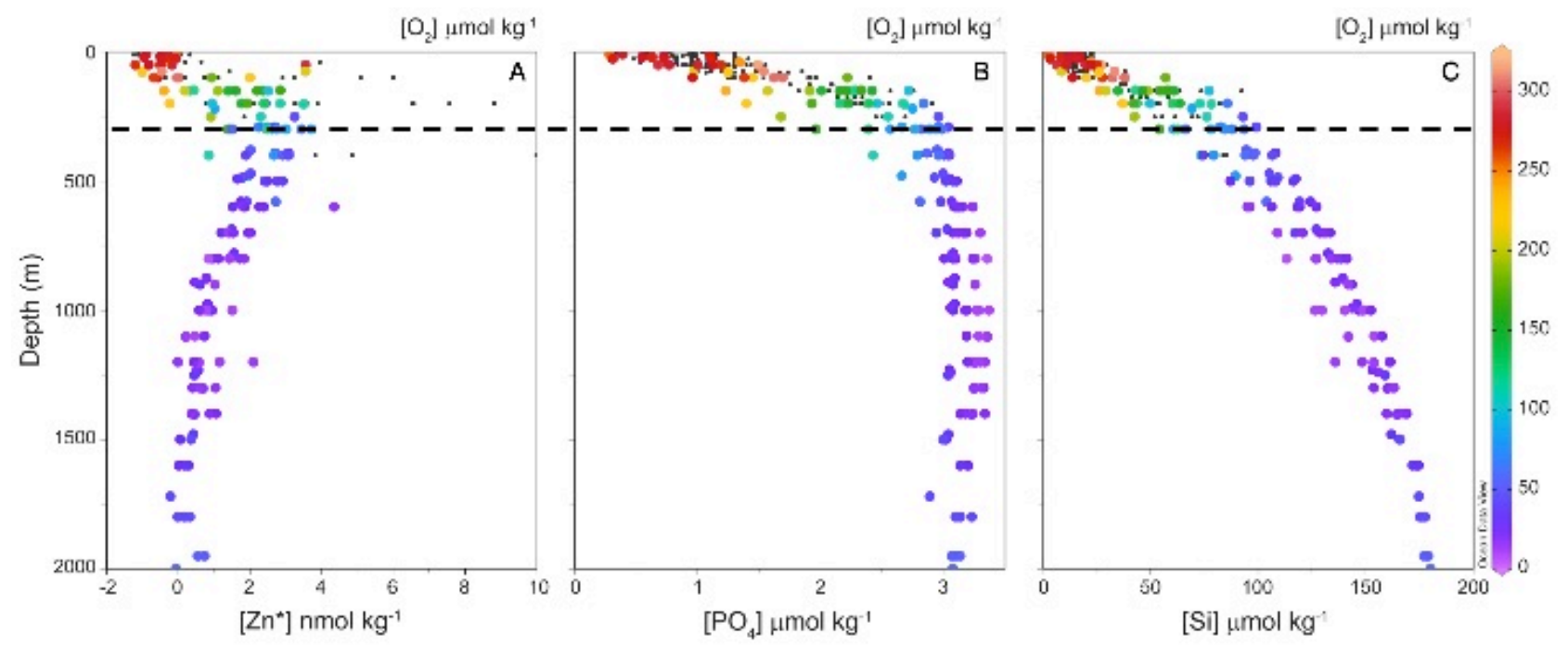

Figure 6: Depth profiles of $\mathrm{Zn}^{*}$ (A, see text for definition), $\mathrm{PO}_{4}(\mathrm{~B})$ and $\mathrm{Si}(\mathrm{C})$ for the $\mathrm{NE}$ Pacific. Colour of the data points denotes dissolved $\mathrm{O}_{2}$ concentrations - scale on right - where available (otherwise data shown as black dots). The horizontal dashed line shows the depth level of the $\mathrm{Zn}$ * high. This peak at around 300m is due to: (1) co-regeneration of $\mathrm{Zn}$ and PO4 from phytoplankton organic matter above and; (2) continued opal dissolution below (C) but minimal further regeneration of $\mathrm{Zn}$ and $\mathrm{PO}_{4}$ (B, Figs. 2-4). 


\section{Vance et al. - Figure 7}
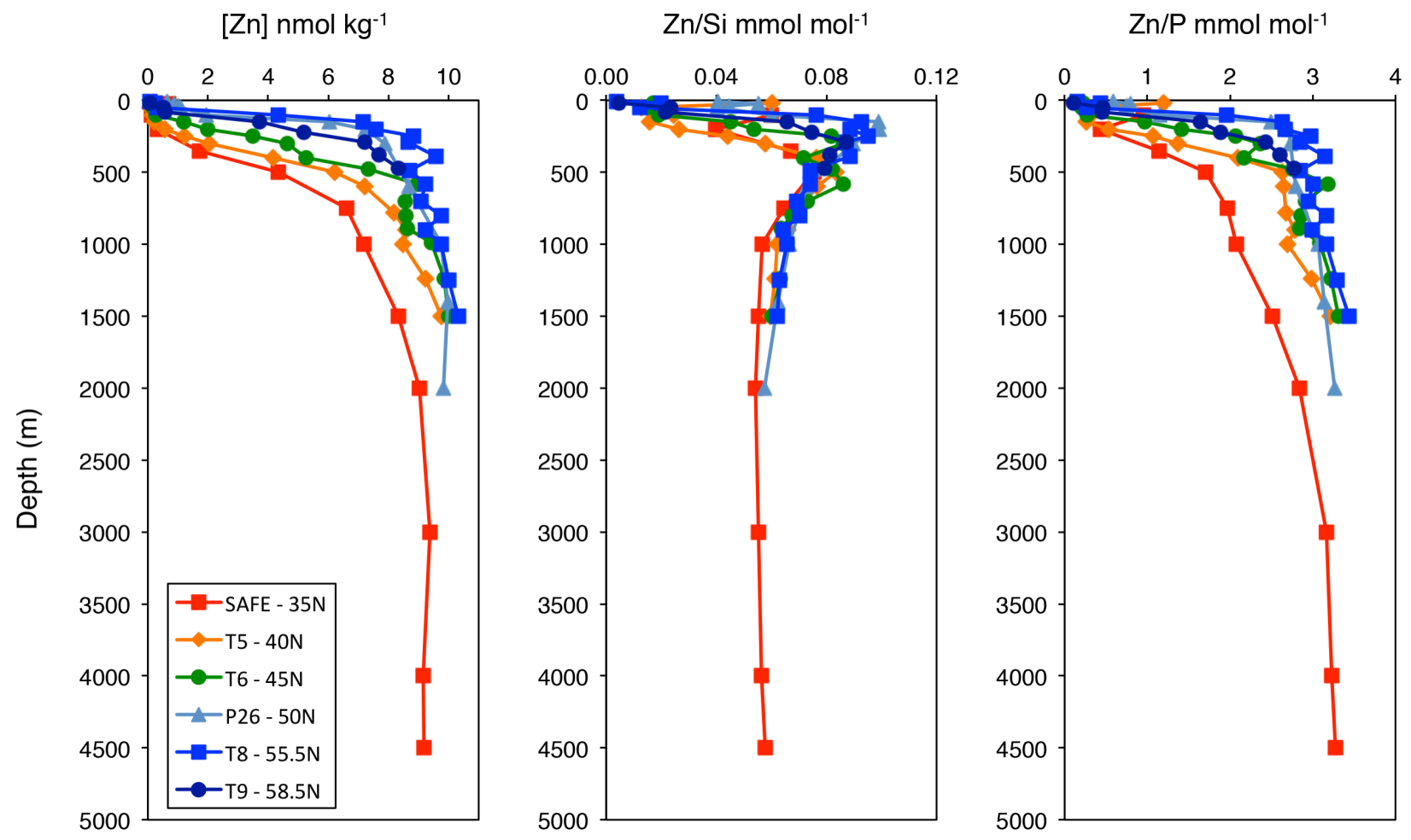

Figure 7: Depth profiles of $\mathrm{Zn}$ concentration, $\mathrm{Zn} / \mathrm{Si}$ and $\mathrm{Zn} / \mathrm{P}$, showing data along a latitudinal transect through the North Pacific from SAFe $\left(35^{\circ} \mathrm{N}\right.$; Conway and John, 2015), from VERTEX stations (Martin et al., 1989) and from this study (P26). 


\section{Vance et al. - Figure 8}

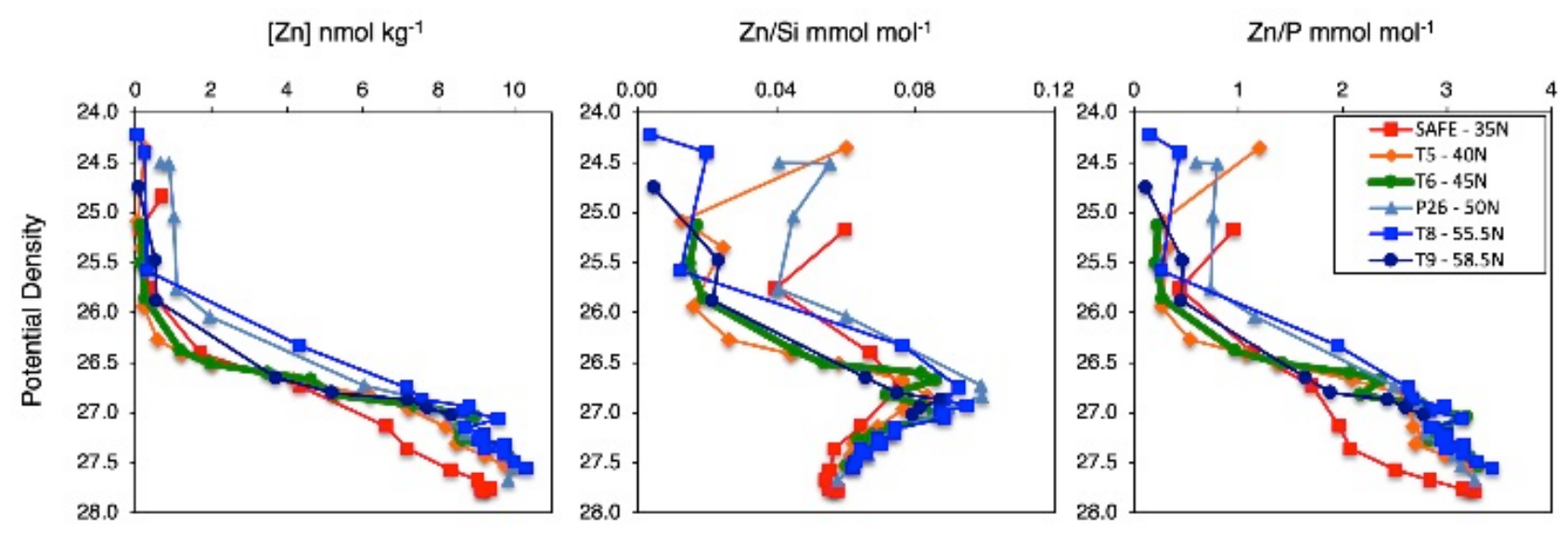

Figure 8: $\mathrm{Zn}$ concentration, $\mathrm{Zn} / \mathrm{Si}$ and $\mathrm{Zn} / \mathrm{P}$, versus potential density, showing the same stations and data from the same sources as in the depth profiles in Fig. 7. 


\section{Vance et al. - Figure 9}

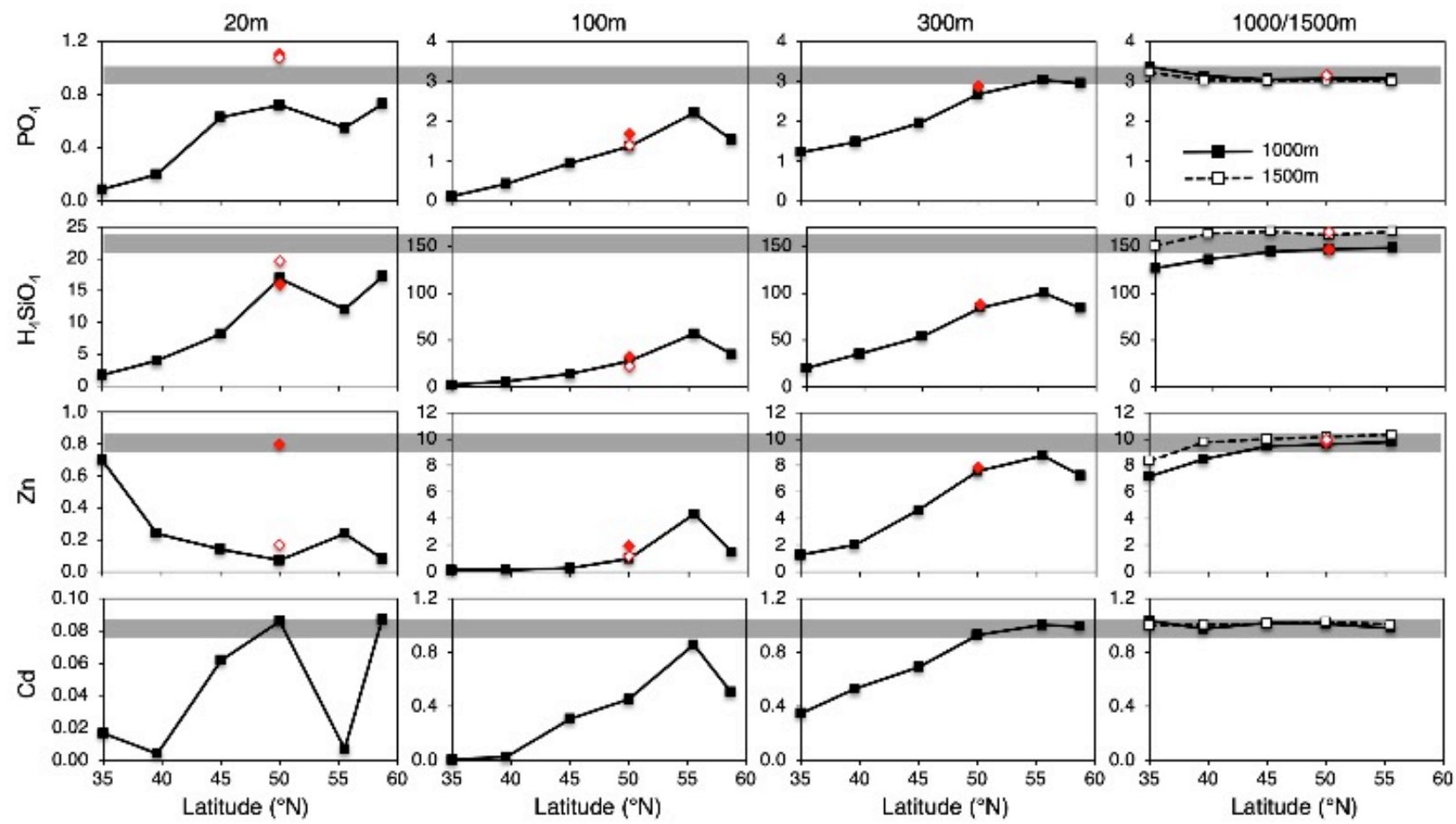

Figure 9: The same data as in Figures 7 and 8, with latitudinal trends shown for specific depths. Note the change in scales between the plots for $20 \mathrm{~m}$ versus the plots for the deeper samples. The squares use data from Conway and John (2015) for SAFe and data from the VERTEX stations for all other latitudes (Martin et al. 1989). Data for P26 from this study (filled red diamonds) and from Lohan et al. (2002) illustrate the range of variation at this station, when available. The data for Zn concentration at P26 again highlight the different nature of the August 2011 dataset, as pointed out in the text for chlorophyll a and other parameters. The grey bands, showing the concentration at $1000 \mathrm{~m}$ for all elements in all panels, highlight the fact that concentrations of all species except Si reach values very close (within $10 \%$ ) to their maxima at about $300-400 \mathrm{~m}$. Silica concentrations, by contrast, increase by a further $70-90 \%$ at depths beneath $300-400 \mathrm{~m}$. 


\section{Supplementary information to}

\section{"The relationship between zinc, its isotopes, and the major nutrients in the North-East Pacific" D. Vance, G. F. de Souza, Y. Zhao, J. T. Cullen, and M. C. Lohan}

\section{Estimating the biological $\mathrm{Zn}$ isotope effect from water column data}

Estimates of the fractionation factor associated with biological uptake needed to produce the observed $\mathrm{Zn}$ concentration and isotopic gradients were calculated using a simple one-dimensional advection-diffusionreaction model of the uppermost water column. Whilst not a realistic representation of the water column, such a model allows consideration of the damping effect of mixing on isotopic gradients in the water column created by biological fractionation. We assess the sensitivity of our results to chosen parameters through a series of sensitivity tests.

\section{Model description and optimisation:}

The model carries tracers of $\mathrm{Zn}$ and ${ }^{66} \mathrm{Zn}$, and simulated biological uptake (which is first order in concentration, with a timescale of 3.75 days) fractionates $\mathrm{Zn}$ isotopes according to a prescribed isotope effect $\varepsilon$. Exported biogenic particles follow exponential remineralisation behaviour with a lengthscale of $480 \mathrm{~m}$ (i.e. corresponding to particulate organic carbon; Sarmiento and Gruber, 2006), with no fractionation during remineralization.

The model was solved as a boundary-value problem (using MATLAB's boundary-value problem solver bvp 4c), with $\mathrm{Zn}$ concentrations at the bottom of the profile and in the surface mixed layer fixed to values observed at each station. The value of $\varepsilon$ providing the best fit to the observed $\delta^{66} \mathrm{Zn}$ data was calculated using non-linear least squares (lsqnonlin).

For our own data from station P04, we compare the model to the upper $75 \mathrm{~m}$ of the water column, such that the lower boundary is within what appears to be a fossil winter mixed layer, and bears a low $\delta^{66} \mathrm{Zn}$ value. We also consider station P3 from Samanta et al. (2017), which is their only station south of the subtropical front, and thus most suitable for comparison to our model; here, we use data from between the surface and 200m, which is below the deep chlorophyll maximum and may also be within a fossil winter mixed layer. For the reader's reference, fitting our model to data from their stations $\mathrm{P} 2$ and $\mathrm{P} 1$ gave values of $\varepsilon$ ranging from $-0.06 \%$ ( $\mathrm{P} 2)$ to $+0.3 \%(\mathrm{P} 1)$, but station $\mathrm{P} 2$ is influenced by a subsurface front (Samanta et al. 2017), making the application of a 1D-model unsuitable, and station P1 exhibits virtually no Zn concentration gradient over the uppermost $200 \mathrm{~m}$, leading to very weak constraints on $\varepsilon$.

\section{Sensitivity tests}

In order to obtain a handle on the sensitivity of $\varepsilon$ to simulated upwelling velocity $w$ and (turbulent) diffusivity $\kappa$, the values of these parameters were changed independently of each other: upwelling velocity was varied from $0 \mathrm{~m} / \mathrm{d}$ to $25 \mathrm{~m} / \mathrm{d}$, based on typical Ekman suction velocities (e.g. Sarmiento and Gruber, 2006), whilst (spatially constant) turbulent diffusivity was varied from $10^{-5}$ to $10^{-4} \mathrm{~m}^{2} / \mathrm{s}$, which is meant to represent the influence of different strengths of stratification (the value of $10^{-5} \mathrm{~m}^{2} / \mathrm{s}$, for instance, is typical for the stratified thermocline; Ledwell et al., 1998). Results are reported in Table S1 below. 
Table S1: Optimised value of biological $\mathrm{Zn}$ isotope effect $\varepsilon$ [\%o]

\begin{tabular}{|c|c|c|c|c|}
\hline & \multicolumn{2}{|c|}{$w=-25 \mathrm{~m} /$ day (upwelling) } & \multicolumn{2}{|c|}{$w=0 \mathrm{~m} / \mathrm{day}($ no advection) } \\
\hline & $\kappa=10^{-5} \mathrm{~m}^{2} / \mathrm{s}$ & $\kappa=10^{-4} \mathrm{~m}^{2} / \mathrm{s}$ & $\kappa=10^{-5} \mathrm{~m}^{2} / \mathrm{s}$ & $\kappa=10^{-4} \mathrm{~m}^{2} / \mathrm{s}$ \\
\hline Station P04 ${ }^{a}$ & -0.22 & -0.30 & -0.30 & -0.30 \\
\hline Station P3 ${ }^{b}$ & -0.22 & -0.32 & -0.34 & -0.34 \\
\hline
\end{tabular}

${ }^{a}$ from this study, water column data from $5-75 \mathrm{~m}$

${ }^{b}$ from Samanta et al. (2017), water column data from $15-200 \mathrm{~m}$

\section{References not cited in the main text}

Ledwell, J.R., Watson, A.J., Law, C.S. (1998). Mixing of a tracer in the pycnocline. J. Geophys. Res. Ocean. $103,21,499-421,529$.

Sarmiento, J.L., Gruber, N. (2006). Ocean Biogeochemical Dynamics. Princeton University Press, Princeton, USA. 503pp. 